\title{
9. CHARACTERIZATION OF ORGANIC MATTER IN DEEP-SEA SEDIMENTS ON THE CHILE CONTINENTAL MARGIN WITH SPECIAL EMPHASIS ON MATURATION IN AN AREA OF HIGH GEOTHERMAL HEAT FLOW ${ }^{1}$
}

\author{
Ralf Littke, ${ }^{2}$ Ulrich Disko, ${ }^{2}$ and Jürgen Rullkötter ${ }^{3}$
}

\begin{abstract}
Ocean Drilling Program Leg 141 core samples drilled offshore of Chile (Sites 859, 860, 861, and 863) were studied for their content and quality of organic matter. Of special interest was the maturity of the organic matter because the sediments were assumed to be influenced by high geothermal heat flow above or near the recently subducted volcanic Chile Ridge.

Total organic carbon contents do not exceed $1 \%$ in any of the samples analyzed. Average percentages decrease slightly with increasing water depth and distance from the coast, from Site 861 toward Site 859. The organic matter is of a mixed marine and terrigenous origin with the proportion of marine organic matter decreasing toward the continent, from Site 859 to Site 861 . Marine organic matter is predominant only in the deeper samples from Site 863 (below about $300 \mathrm{mbsf}$ ).

Although formation temperatures are in the range of $85^{\circ}$ to $90^{\circ} \mathrm{C}$ at Site 863 and both Sites 859 and 863 are located close to the ridge axis, most of the organic matter maturity parameters reflect low thermal stress. For example, vitrinite reflectance values are lower than $0.4 \%$, the $20 S /(20 S+20 R)$ epimer ratios of 24 -ethylsteranes and the $22 S /(22 S+22 R)$ epimer ratios of 30-homohopanes are low in most samples, and unsaturated hydrocarbons such as sterenes and hopenes are abundant. On the other hand, the concomitant presence of saturated biological marker hydrocarbons with a petroleum-like distribution in several of the sediment samples from Site 859 indicates an advanced level of maturation. This pattern is explained by mixing of autochthonous bitumen constituents bearing an immature signature with small amounts of migrated hydrocarbons which were formed under the influence of hydrothermal fluids or other geothermal stress probably in a deeper section. This effect was not observed at Site 863.

The diagenetic evolution at Site 863 , as expressed by vitrinite reflectance values, may be explained tentatively as resulting from rapid heating to the present-day temperatures over a period of only several thousand rather than several million years.
\end{abstract}

\section{INTRODUCTION}

Ocean Drilling Program (ODP) Leg 141 was planned to explore the effects of a subducted "mid-ocean" ridge on forearc sediments at the Chile Triple Junction. Main objectives included the determination and quantification of vertical motion within the forearc resulting from plate collision as well as the detection of the seaward limit of continental crust along the forearc near the collision zone (Shipboard Scientific Party, 1992).

The principal goal of our investigation is the characterization of organic matter in the young (Pliocene and Pleistocene) sediments drilled offshore Chile, which may provide a key for the understanding of the processes that controlled the deposition of organic matter in more ancient sediments. For example, constraints on water depth and distance to the coast are much less speculative for Neogene deposits than for Mesozoic and Paleozoic strata. Furthermore, samples taken during Leg 141 are of special interest, because they offer the possibility to study sedimentary organic matter from the Southern Oceans (south of $45^{\circ} \mathrm{S}$ ). A short summary of the rare organic geochemical studies on samples from southern high latitudes is presented by Kvenvolden et al. (this volume).

The interest in addressing the maturation of organic matter as our second objective is related to the tectonic position of the Chile continental margin, where the volcanic Chile Ridge is subducted beneath the South American continental plate. This situation is unique, because active spreading centers, characterized by extremely high heat flow, are usually not covered by a thick sequence of sediments (compare results of ODP Leg 139; Davis, Mottl, Fisher, et al., 1992).

\footnotetext{
'Lewis, S.D., Behrmann, J.H., Musgrave, R.J., and Cande, S.C. (Eds.), 1995. Proc. ODP, Sci. Results, 141: College Station, TX (Ocean Drilling Program).

${ }^{2}$ Institut für Erdöl und Organische Geochemie (ICG-4), Forschungszentrum Jülich GmbH, D-52425 Jülich, Federal Republic of Germany.

${ }^{3}$ Institut für Chemie und Biologie des Meeres (ICBM), Carl von Ossietzky Universität Oldenburg, P.O. Box 2503, D-26111 Oldenburg, Federal Republic of Germany.
}

In the case of the Chile continental margin at about $46^{\circ} \mathrm{S}$, sediments of several hundred, possibly even more than a thousand, meters thickness were deposited above the subducted ridge and are affected by the local high heat flow. Formation temperatures of about $85^{\circ} \mathrm{C}$ to $90^{\circ} \mathrm{C}$ were determined at total depth in Hole 863B (Sawyer, this volume) at a site where the Chile Ridge presently is subducted. This temperature measurement indicates a geothermal gradient of $100^{\circ} \mathrm{C} / \mathrm{km}$ and more in the uppermost part of the crust. A similar geothermal gradient was calculated for the shallower Site 859 (Behrmann, Lewis, Musgrave, et al., 1992). Under these circumstances, it was expected that a clear downhole maturity trend could be established for the organic matter at these "hot" sites, because organic matter transformation usually is more sensitive to temperature rise than mineral diagenesis. Until now, only a few sediments had been drilled in the deep sea that had reached organic matter maturities approaching the onset of thermal petroleum generation (e.g., Rullkötter et al., 1981; Simoneit, 1982; von der Dick et al., 1983; Davis, Mottl, Fisher, et al., 1992; Lichtfouse et al., 1992), because most holes did not recover more than several hundred meters of sediment and because heat flow usually is low at passive continental margins where the thicker sedimentary sequences were penetrated. Therefore, the hot Chile continental margin is one of the few locations where significant thermal maturation may occur in a sequence of sediments from the deep ocean that can be reached within the technical limits of the JOIDES Resolution.

\section{GEOLOGIC BACKGROUND}

Sediment cores were recovered from five sites along the Chile continental margin during Leg 141 operations. We present and discuss organic geochemical and organic petrologic data for samples from Sites $859,860,861$, and 863 .

Drilling at Sites 859,860 , and 861 was performed along an eastwest transect at $45^{\circ} 51^{\prime} \mathrm{S}$ latitude (Fig. 1). Site 861 is situated closest to the coast at a distance of $10 \mathrm{~km}$ from the outer edge of the continental shelf and at a water depth of about $1650 \mathrm{~m}$. Sites 860 and 859 


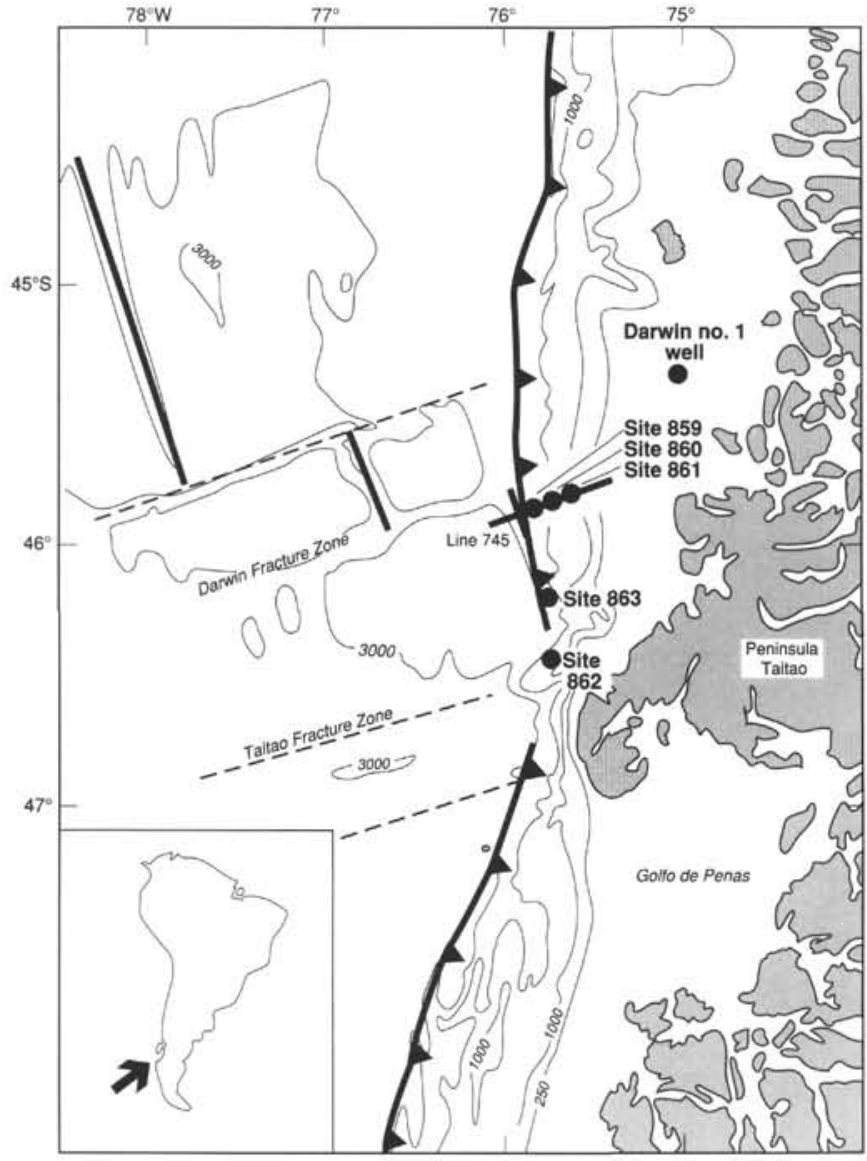

Figure 1. Tectonic map of the southeast Pacific between $44^{\circ}$ and $48^{\circ} \mathrm{S}$. Heavy solid lines mark segments of the spreading center, the dashed lines indicate transform faults of the Chile Ridge, and the saw-toothed line delineates the overthrust of the South American forearc. Sites 859, 860,861, and 863 were drilled during Leg 141. Contour level in meters.

are located at a greater distance from the shelf (19 and $26 \mathrm{~km}$, respectively), where the water depth is 2145 and $2740 \mathrm{~m}$, respectively. A rough interpretation of the geology along this transect is illustrated in Figure 2 (Behrmann, Lewis, Musgrave, et al., 1992). Owing to the proximity to the coast, terrigenous and shallow marine material was transported in slumps, debris flows, and turbidity currents to these sites, where these were mixed with pelagic material. These mixed pelagic-turbiditic deposits are underlain by a sequence of tectonically accreted trench sediments. Most deposits in both units are fine-grained siliclastics with little carbonate and biogenic silica admixed. They were classified mainly as silty clays and clayey silts by the shipboard sedimentologists. Few coarser grained sediments occur at Sites 861 and 859. Structural deformation was observed at all sites. Stratigraphically, the sediments at Sites 861 and 860 are of late Pliocene through late Pleistocene age. At Site 859 , only $10 \mathrm{~m}$ of upper Pleistocene materials overlie an upper Pliocene sequence.

High temperature gradients were established for Site 859 (Behrmann, Lewis, Musgrave, et al., 1992; Shipboard Scientific Party, 1992). According to logging results (Sawyer, this volume), formation temperatures of about $90^{\circ} \mathrm{C}$ are expected for the sediments at the terminal depth of $476 \mathrm{~m}$ below seafloor (mbsf). This implies an average geothermal gradient of more than $150^{\circ} \mathrm{C} / \mathrm{km}$ for the near-surface sequence. The gradient probably decreases at greater depth because of the higher heat conductivity of more consolidated sediments. The high formation temperatures at Site 859 were a surprise, because the sediments do not directly overlie the subducted Chile Ridge (Fig. 1). Therefore, lateral heat transport may be effective in the crust between the volcanic center and Site 859 . Heat may also be advected from deep parts of the forearc subduction zone.

Site 863 is situated in an accretionary wedge, at a point directly above the subducted spreading axis at the base of the trench slope and south of the transect between Sites 859 and 861 (Figs. 1 and 3). Water depth is $2564 \mathrm{~m}$ and the distance from the outer shelf edge is about 20 $\mathrm{km}$. Sediments are mainly fine-grained siliclastics (clayey siltstones and silty claystones) interlayered with some coarser-grained layers. Sediment deformation is strong to the extent that an almost vertically dipping unit was cored between about $300 \mathrm{mbsf}$ and total depth at 743 mbsf. This observation of strong deformation is supported by paleontological data. According to nannofossil stratigraphy, the lower part of the sediments recovered from Hole 863A ( 230 to $297 \mathrm{mbsf}$ ) is of early Pleistocene age, whereas the sediments drilled in Hole 863B ( 300 to $743 \mathrm{mbsf}$ ) are of late Pleistocene age (i.e., younger than the "overlying" sediments of the adjacent Hole 863A).

Because of ridge subduction, an extremely high heat flow and evidence for vigorous hydrothermal circulation were expected at Site 863. Formation temperatures were calculated to be at about $90^{\circ} \mathrm{C}$ at total depth, corresponding to an average geothermal gradient of about $100^{\circ}-110^{\circ} \mathrm{C} / \mathrm{km}$. Surprisingly, this value is not higher than the gradient calculated for the area north of the subducted Chile Ridge (Site 859).

In view of the geological constraints described above, the upper Pliocene intervals from Sites 861 and 859 appear to be most suitable for a study of organic facies, because rocks of similar stratigraphic age were cored at different distances from the coast and at different water depths. Changes in organic matter content and quality can therefore be attributed to the influence of either one of the two controlling mechanisms above. In addition, the organic facies of the lower Pleistocene sediments drilled in the vertical unit below 300 mbsf at Site 863 will be presented. With respect to maturation, only the "hot" Sites 859 and 863 will be discussed. Fluorescence of liptinite macerals and gas chromatograms of saturated hydrocarbons provided clear (though not quantitative) evidence that the maturation of organic matter did not progress significantly with depth at Sites 860 and 861 .

\section{METHODS}

Sediment samples were received frozen and after thawing were dried at $40^{\circ} \mathrm{C}$. Whole-rock aliquots were set aside for kerogen microscopy, and the remainder was ground in a disc mill. Total carbon and total organic carbon (TOC) were determined by combustion in a LECO IR-112 carbon analyzer. The latter measurement was performed after treatment of the samples with hydrochloric acid to remove carbonates. As inorganic carbon percentages do not exceed $1 \%$ and carbonate percentages do not exceed $6 \%$ in the samples drilled during Leg 141 operations, these values are not further discussed here.

Rock-Eval pyrolysis was performed using a Rock-Eval II instrument (Girdel). Hydrogen Index (HI) and Oxygen Index (OI) values were determined from flame ionization detector (FID) and thermal conductivity detector (TCD) responses and are expressed as mg hydrocarbon-type material per $\mathrm{g}$ TOC ( $\mathrm{mg} \mathrm{hc/g} \mathrm{TOC)}$ and $\mathrm{mg}$ carbon dioxide per gram TOC $\left(\mathrm{mg} \mathrm{CO}_{2} / \mathrm{g} \mathrm{TOC}\right)$, respectively. For microscopic studies, whole-rock samples were embedded in a resin in an orientation perpendicular to bedding, and then ground flat and polished. Maceral group percentages were estimated first in reflected white light (for vitrinite and inertinite), and then in a fluorescence mode (for liptinite) on a Zeiss Axiophot microscope. Vitrinite reflectance $\left(R_{\mathrm{r}}\right)$ was measured in oil immersion at $546 \mathrm{~nm}$. $R_{\mathrm{r}}$ values presented here are mean values based on measurements of at least 30 individual vitrinite grains.

Twelve selected samples from Sites $861,860,859$, and 863 were dried and extracted by flow-blending (Radke et al., 1978) with dichloromethane-methanol (99:1). Total extracts were separated into several compound classes by medium-pressure liquid chromatography (Radke et al., 1980). Saturated hydrocarbon fractions were analyzed using a VEGA 6180 gas chromatograph (Carlo Erba Strumentazione, 

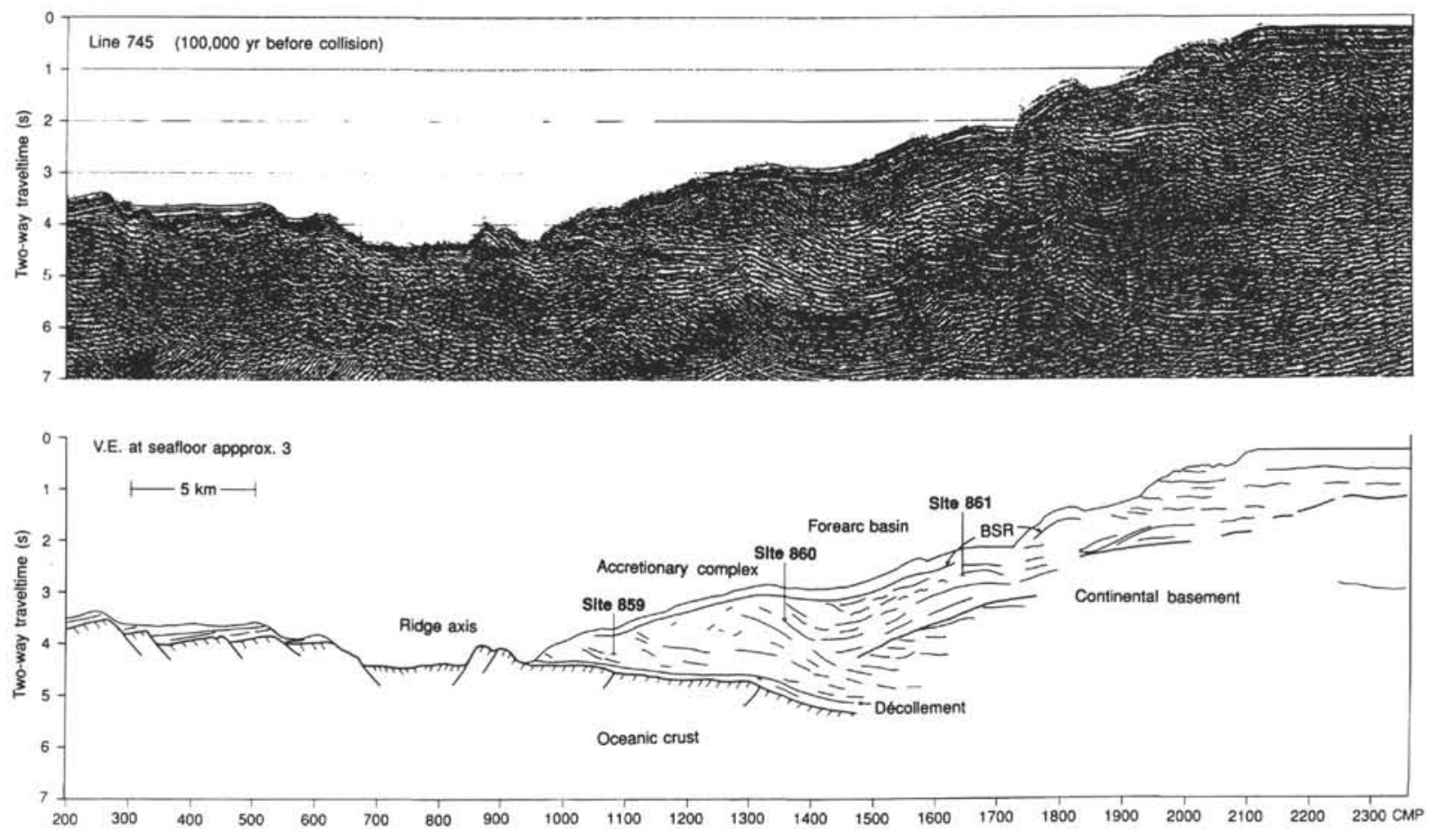

Figure 2. Cross-section of the South American continental margin (seismic line 745) with location of Sites 859, 860, and 861.
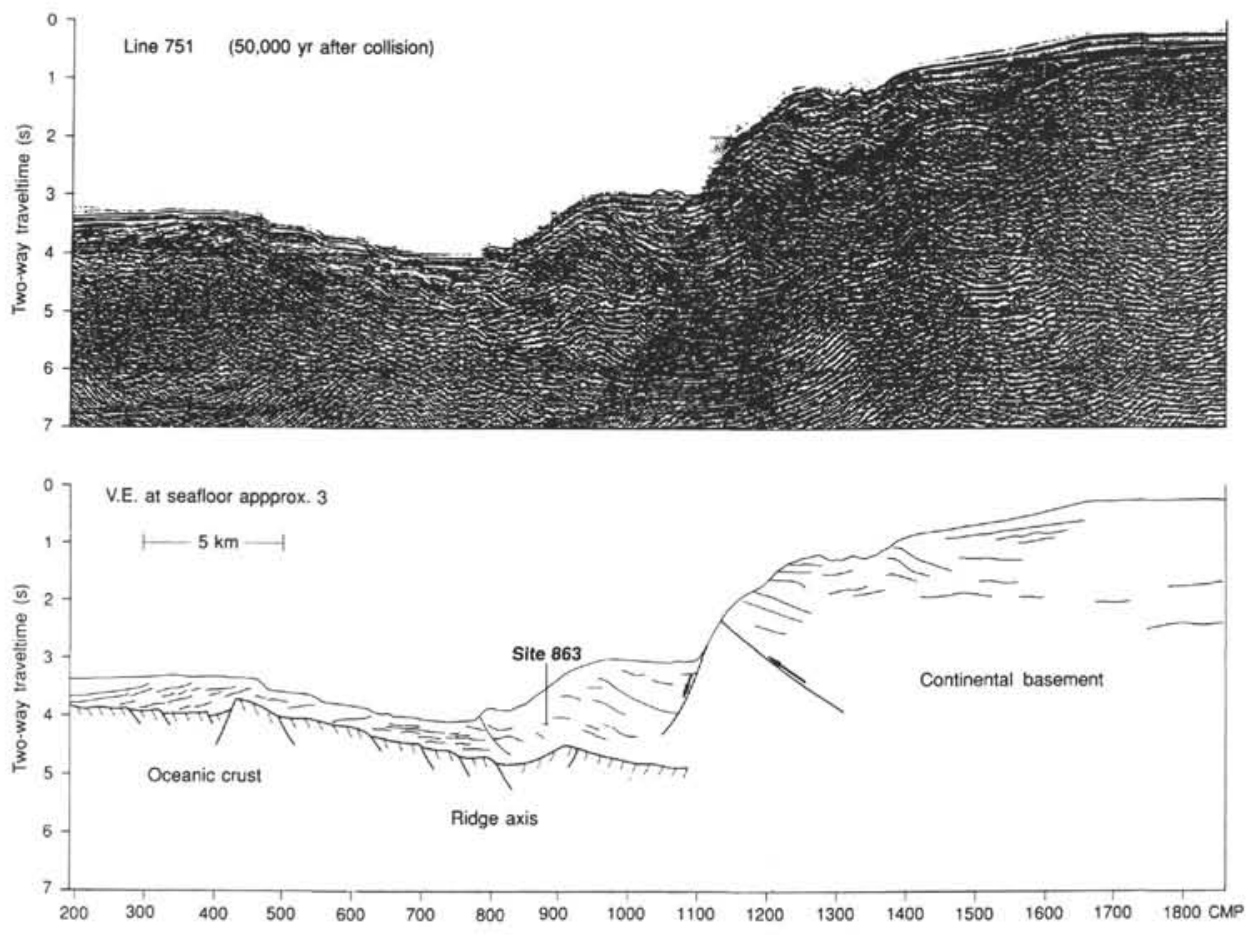

Figure 3. Cross-section of the South American continental margin (seismic line 751) with location of Site 863.

Milano) equipped with a fused-silica capillary column ( $25 \mathrm{~m}$ length, internal diameter of $0.32 \mathrm{~mm}$ ) coated with cross-linked SE 54 polysiloxane of $0.25-\mu \mathrm{m}$ film thickness. Splitless sample introduction was performed by direct, "on-column" injection of the dissolved samples. The oven temperature was programmed from $60^{\circ} \mathrm{C}$ (hold for $1 \mathrm{~min}$ ) at $30^{\circ} \mathrm{C} / \mathrm{min}$ to $80^{\circ} \mathrm{C}$, and then at $4^{\circ} \mathrm{C} / \mathrm{min}$ to $300^{\circ} \mathrm{C}$ (hold for $30 \mathrm{~min}$ ). Helium was used as the carrier gas.
For gas chromatography-mass spectrometry (GC-MS) analysis a VG 7070 E mass spectrometer coupled to a Carlo Erba Fractovap model 4160 gas chromatograph was used. Ionization energy was 70 $\mathrm{eV}$, and the source was held at $220^{\circ} \mathrm{C}$. Samples were introduced via a cold-trap injection system (KAS 2, Gerstel) onto a fused-silica capillary column ( $50 \mathrm{~m}$ length, $0.32-\mathrm{mm}$ inner diameter) coated with Ultra 2 (SE 54 equivalent, $0.25 \mu \mathrm{m}$ film thickness). Helium was used as 
carrier gas and the oven programmed from $110^{\circ}$ to $300^{\circ} \mathrm{C}$ at $3^{\circ} \mathrm{C} / \mathrm{min}$ with a $30 \mathrm{~min}$ final hold time. The magnet of the mass spectrometer was scanned in a cyclic mode over a mass range of $\mathrm{m} / \mathrm{z} 800-45$ (cycle time $\approx 2 \mathrm{~s} / \mathrm{scan}$ ). Data were acquired, stored, and processed using a Kratos DS-90 data system. Compound identification is based on mass spectral interpretation, relative retention time, and comparison with published mass spectral information.

\section{ORGANIC MATTER CONTENT}

TOC contents were measured on board JOIDES Resolution (Behrmann, Lewis, Musgrave, et al., 1992) and in our shorebased laboratory. Both sets of data are plotted together in Figures $4 \mathrm{~A}-\mathrm{D}$ for Sites $861,860,859$, and 863 , respectively, and data of closely spaced samples in general are in good agreement with each other. In immature sediments, the percentage of organic matter exceeds the percentage of organic carbon by a factor of 1.5 to 2.0 (see data in Rullkötter et al., 1988, for mainly aquatic organic matter and in Schenk et al., 1990 , for coaly organic matter).

At Site 861 , TOC values are fairly consistently at or close to $0.4 \%$, except for the upper $30 \mathrm{~m}$, where they cluster near $0.6 \%$ (Fig. 4A). Slightly enhanced TOC values were common in the upper sections of deep-sea sediments and attributed either to the establishment of upwelling conditions and related bioproductivity increase (Stein, ten Haven, et al., 1989; ten Haven et al., 1990) or to an enhanced accumulation of terrigenous sediments including terrigenous organic matter (Littke et al., 1991). Also, the lesser degree of remineralization in the uppermost sediments compared to deeper sediments may influence TOC profiles. For the upper Pliocene, the average TOC content is $0.41 \%$ at Site 861 (Table 1).

At Site 860, TOC values are at the same level as at Site 861. However, with the exception of the two uppermost samples (upper 5 $\mathrm{m})$, no increase of TOC contents toward the top of the sequence was found (Fig. 4B). Interestingly, this small interval of "high" TOC values stratigraphically corresponds to the thicker interval of "high" TOC values at Site 861 , and both represent the last $250,000 \mathrm{yr}$. An average organic carbon percentage was calculated for the upper Pliocene $(0.4 \%$, Table 1$)$, which was entirely penetrated at Site 860 . This value was converted into an accumulation rate using the following relationship (van Andel et al., 1975; Stein, Littke, et al., 1989):

$$
\text { AROC }=(T O C / 100) \cdot L S R \cdot(W B D-1.026 P O / 100) .
$$

In this equation, $A R O C$ is the mass accumulation rate for organic carbon $\left(\mathrm{g} / \mathrm{cm}^{2} / 1000 / \mathrm{a}\right), L S R$ is the linear sedimentation rate $(\mathrm{cm} / 1000 /$ a), WBD is the wet-bulk density $\left(\mathrm{g} / \mathrm{cm}^{3}\right)$, and $P o$ is the porosity of the sediment (\%). $L S R, W B D$, and Po were calculated according to the information in Behrmann, Lewis, Musgrave, et al. (1992) and some additional stratigraphic information from D. Spiegler (pers. comm., 1993). In the case of Site 860, "sedimentation rate" means the sum of sedimentation and the tectonic thrusting rate and should be regarded as only a rough estimate of the organic matter accumulated by both processes at this site. Numerically, the accumulation rate for organic carbon calculated this way is about $20 \mathrm{~g} / \mathrm{cm}^{2} / 1000 / \mathrm{a}$. This rate is similar to rates calculated for other near-continent settings in areas of temperate climate such as in the Labrador Sea, but is lower by an order of magnitude than the accumulation rates in intercontinental deep-sea areas such as Baffin Bay (Stein, Littke, et al., 1989). The rate is 4 to 40 times higher than accumulation rates for organic carbon in sedimentstarved areas in the oceans (Indian Ocean ridges; Littke et al., 1991).

For the more distal Site 859, lower TOC values were measured than for sediments from Sites 860 and 861 . An obvious exception are the upper $30 \mathrm{~m}$, which are characterized by higher percentages of organic carbon (Fig. 4C). Stratigraphically, this interval covers the last $250,000 \mathrm{yr}$ (upper $13 \mathrm{~m}$ ) as at Sites 860 and 861 , but also part of the upper Pliocene. For the upper Pliocene, the average organic carbon percentage is about $0.1 \%$ lower than at Sites 861 and 860 . In more distal parts of the oceans, TOC values are usually even lower than at
Site 859 ; for example, TOC values vary between $0 \%$ and $0.2 \%$ in Neogene sediments in the central Indian Ocean (Littke et al., 1991) and in the western Pacific Ocean (Parson, Hawkins, Allan, et al., 1992). The latter areas are several thousand kilometers away from shorelines and shelves.

In the case of the Chile continental margin, the decrease in organic carbon percentages by $25 \%$ toward the ocean is not paralleled by a decrease in organic carbon accumulation rates, because the upper Pliocene is thicker at the distal Site 859 (at least $463 \mathrm{~m}$ ) than at Sites 860 and 861 . This increase in thickness is probably not the effect of an increase in sedimentation rates but rather may be caused by tectonic thrusting (Behrmann, Lewis, Musgrave, et al., 1992).

\section{KEROGEN QUALITY}

Kerogen is defined as the insoluble organic matter in sediments (Durand, 1980), whereas the part of the sedimentary organic matter that is extractable by organic solvents is called bitumen. As in most rocks, kerogen forms more than $90 \%$ of the organic matter in all samples drilled from offshore Chile during Leg 141. Kerogen characterization was performed by microscopic methods and by Rock-Eval pyrolysis on whole rocks and on concentrated kerogens.

Rock-Eval pyrolysis data are usually unreliable if measured on immature sediments with organic carbon concentrations lower than 1\% (Katz, 1983). Therefore, kerogen concentrates were prepared from selected samples and were used for Rock-Eval pyrolysis. Results are summarized in Table 2. Among the Rock-Eval parameters, $\mathrm{HI}$ values are a measure of the hydrocarbon generation potential of kerogen and depend on its hydrogen content. According to Espitalié et al. (1977), an HI value of $150 \mathrm{mg}$ hc/g TOC corresponds to an atomic $\mathrm{H} / \mathrm{C}$ ratio of about 0.9 . Well-preserved marine organic matter is usually rich in hydrogen $(\mathrm{H} / \mathrm{C}>1.2)$ and characterized by high $\mathrm{HI}$ values, whereas hydrogen-poor terrigenous organic matter derived from higher land plants is characterized by lower $\mathrm{HI}$ values (less than $350 \mathrm{mg} \mathrm{hc} / \mathrm{g}$ TOC). Another Rock-Eval parameter is the temperature of maximum pyrolysis yield $\left(\mathrm{T}_{\max }\right)$, which is a measure of the maturity of kerogen. Generally, $T_{\max }$ values increase with increasing maturity and $\mathrm{T}_{\max }$ values below $420^{\circ} \mathrm{C}$ are indicative of immature organic matter. OI values are a measure of the carbon dioxide generation potential of kerogen and depend on its oxygen content. According to Espitalié et al. (1977), an OI value of $50 \mathrm{mg} \mathrm{CO}_{2} / \mathrm{g}$ TOC corresponds to an atomic $\mathrm{O} / \mathrm{C}$ ratio of about 0.3 . High OI values are typical of immature organic matter. Usually, marine organic matter is characterized by lower OI values than terrigenous kerogen.

In Figures $5 \mathrm{~A}$ and $\mathrm{B}, \mathrm{HI}$ and $\mathrm{OI}$ values determined on kerogen concentrates and on whole-rock samples, respectively, are compared. OI values measured on whole-rock samples are clearly and conspicuously high and caused by low-temperature $\left(<390^{\circ} \mathrm{C}\right)$ decomposition of carbonates. HI values measured on whole-rock samples in most cases are lower than those measured on kerogen concentrates. This effect probably results from an adsorption of pyrolytically-generated hydrocarbons on mineral surfaces (mineral matrix effect). S2 values for whole-rock samples are with few exceptions lower than $1 \mathrm{mg}$ hydrocarbon-equivalents/g rock.

More reliable Rock-Eval data were obtained by the analysis of kerogen concentrates for which S2 values varied between 6 and 40 $\mathrm{mg}$ hydrocarbon-equivalents/g rock. The respective $\mathrm{HI}$ values are lowest in sediments from the deeper part of Hole 859B, where OI values are also low. This points toward a predominance of a strongly degraded, inert kerogen in this interval (Table 2) with only a minor contribution of labile kerogen. A higher $\mathrm{HI}$ value was obtained for the sample from the shallowest core drilled at Site 859 as well as for the uppermost samples investigated at Sites 861 and 863 (Table 2). Especially at the latter two sites, preservation of partly marine organic matter in the upper Pleistocene was apparently reasonably good and led to sediments enriched in organic carbon at these locations (see Fig. 4). The high OI values in these samples are tentatively interpreted as 

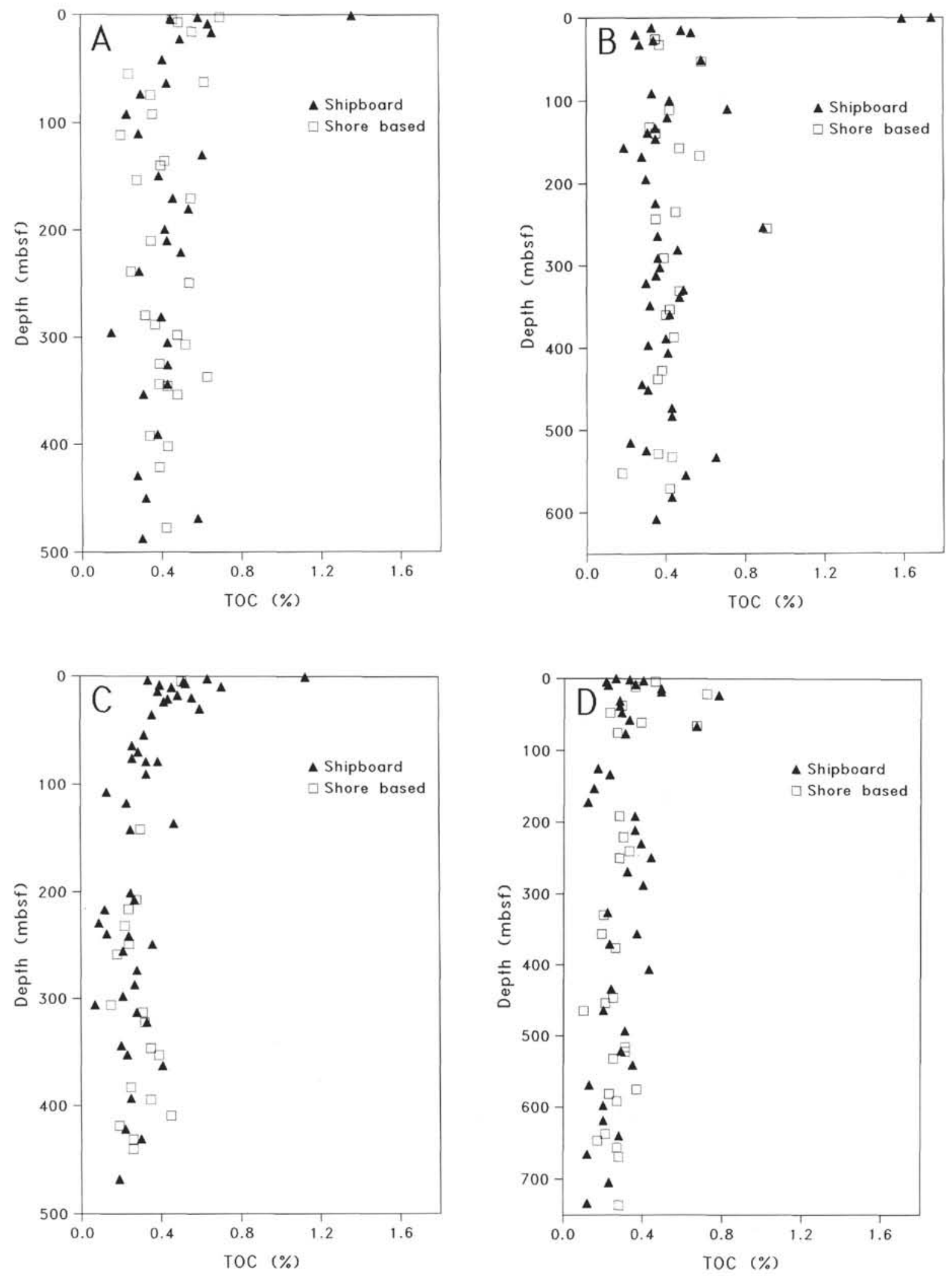

Figure 4. TOC percentages plotted vs. sub-bottom depth for sediments from (A) Sites 861, (B) 860, (C) 859, and (D) 863. 
A

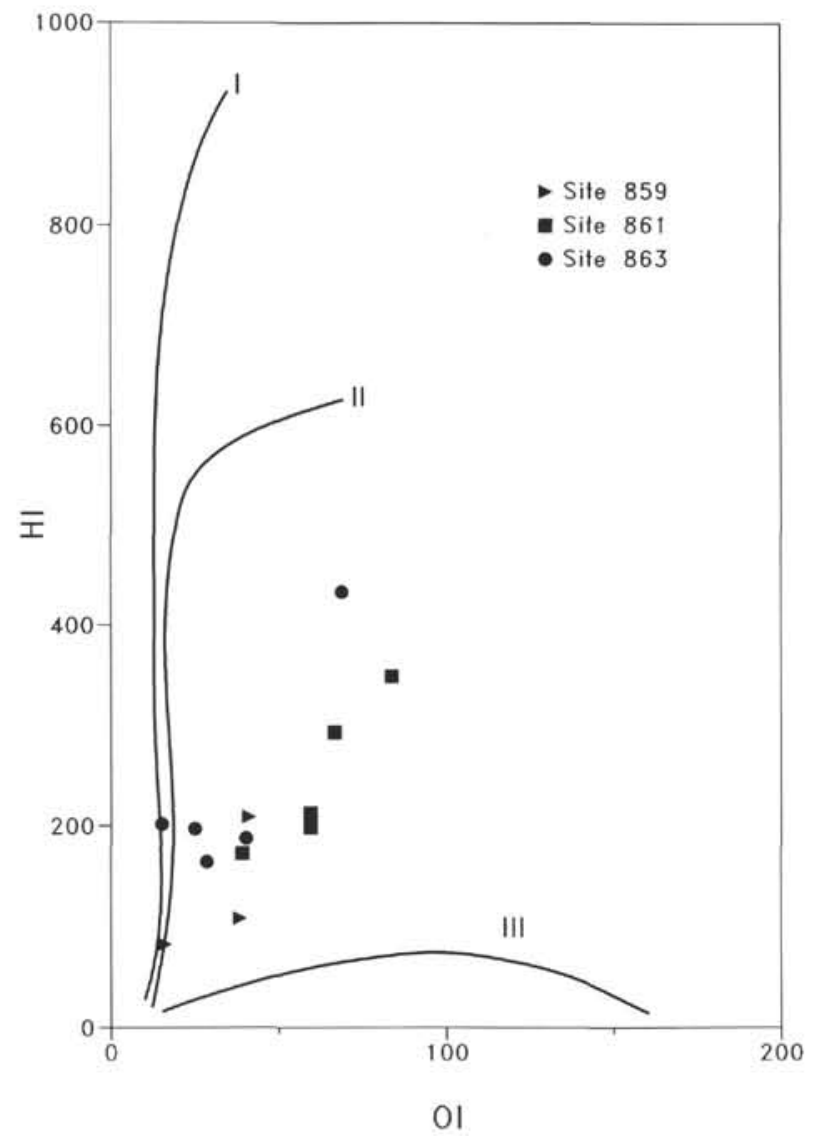

B

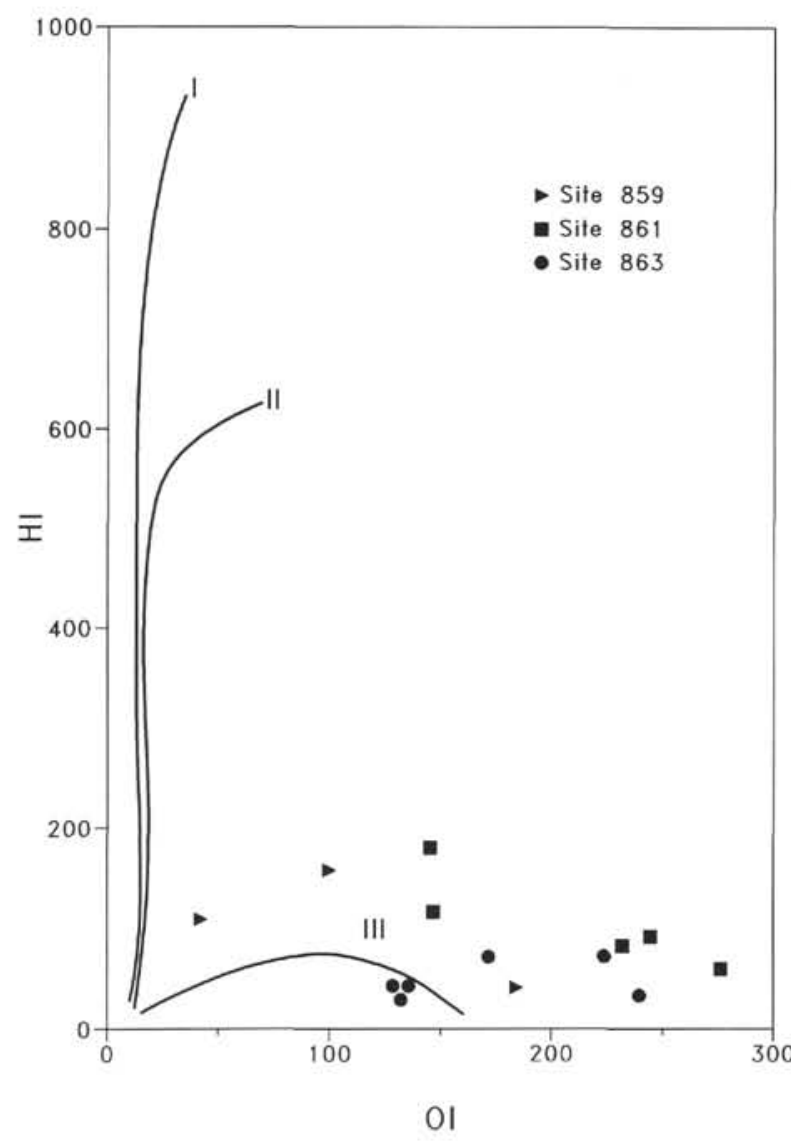

Figure 5. Hydrogen index (mg hydrocarbons/g TOC) values plotted vs. oxygen index ( $\mathrm{mg} \mathrm{CO}_{2} / \mathrm{g} \mathrm{TOC}$ ) values for (A) kerogen concentrates and (B) wholerock samples.

Table 1. Average total organic carbon (TOC) percentages $( \pm$ standard deviation) for specific stratigraphic intervals and depth ranges at Sites $861,860,859$, and 863 (Fig. 4).

\begin{tabular}{|c|c|c|c|c|c|}
\hline Site & $\begin{array}{c}\text { Water } \\
\text { depth } \\
\text { (m) }\end{array}$ & $\begin{array}{l}\text { Distance } \\
\text { from shelf } \\
(\mathrm{km})\end{array}$ & $\begin{array}{l}\text { Stratigraphic } \\
\text { interval }\end{array}$ & $\begin{array}{l}\text { Depth } \\
\text { range } \\
\text { (mbsf) }\end{array}$ & $\begin{array}{l}\text { TOC } \\
(\%)\end{array}$ \\
\hline 861 & 1650 & 10 & upper Pliocene & $170-496$ & $0.41 \pm 0.10(34)$ \\
\hline 860$)$ & 2145 & 19 & upper Pliocene & $|28-53|$ & $0.40 \pm 0.14(42)$ \\
\hline 859 & 2740 & 26 & upper Pliocene & $1.3-476$ & $0.29 \pm 0.11(56)$ \\
\hline 863 & 2565 & 20 & $\begin{array}{l}\text { upper Pliocene/ } \\
\text { lower Pleistocene }\end{array}$ & $230-734$ & $0.26 \pm 0.08(40)$ \\
\hline
\end{tabular}

Note: Number of analyzed samples indicated in parentheses.

resulting from a significant contribution of terrigenous organic matter and a preservation of labile, oxygen-bearing functional groups.

The HI values in the deeper samples at Site 861 vary between 170 and $290 \mathrm{mg} \mathrm{hc} / \mathrm{g}$ TOC and indicate the dominance of either terrigenous organic matter or degraded marine organic matter. Similar values were determined for the deeper sediments drilled at Site 863 . The latter samples, however, are characterized by much lower OI values, indicating a marine rather than a terrigenous source. In contrast to this, kerogens at Site 861 are characterized by high OI values that favor a terrigenous organic matter source.

$\mathrm{T}_{\max }$ values between $390^{\circ}$ and $420^{\circ} \mathrm{C}$ indicate the presence of thermally immature organic matter at all sites (Table 2). The only exception is Sample 141-863B-41R-3, 92-97 cm, for which a $\mathrm{T}_{\max }$ value of $430^{\circ} \mathrm{C}$ was determined. This value corresponds to those of kerogens that have reached the initial stage of petroleum generation. However, the samples below and above are characterized by lower $T_{\max }$ values. Therefore, the higher value for Sample 141-863B-41R-3, $92-97 \mathrm{~cm}$, is tentatively interpreted as either the effect of locally higher maturity or caused by a different type of organic matter in this sample.

In summary, the highest $\mathrm{HI}$ values pointing toward the presence of well-preserved marine organic matter were found for the upper Pleistocene deposits at Sites 859, 861, and 863. For older samples, Rock-Eval data exclude the presence of well-preserved marine organic matter in significant amounts and do not indicate the onset of petroleum generation for the drilled intervals.

According to the microscopic studies on whole-rock samples (which were found to provide more reliable results than those on powdered kerogen concentrates containing particles in oblique orientation to bedding), inertinite is the predominant maceral group at all sites as shown by the compositional estimates summarized in Table 3 . Liptinite and vitrinite occur in minor quantities, and most liptinite is derived from marine organisms, although terrigenous liptinite, such as cutinite, occurs as well. In TOC-lean sediments from the deep sea, inertinite predominance is common (Fig. 6; Littke, 1993). Liptinite is the major maceral group in many marine organic-matter-rich rocks such as the well-known Cenomanian-Turonian black shales. Vitrinite commonly predominates in fluvial and deltaic environments, but rarely in deep-sea deposits.

The predominance of inertinite at Site 859 is in agreement with the low HI values determined for the deeper samples from this site (Table 2). Also, the low OI values of these samples fit well to the relatively low vitrinite content. In contrast to Sites 860 and 861 , vitrinite is less 


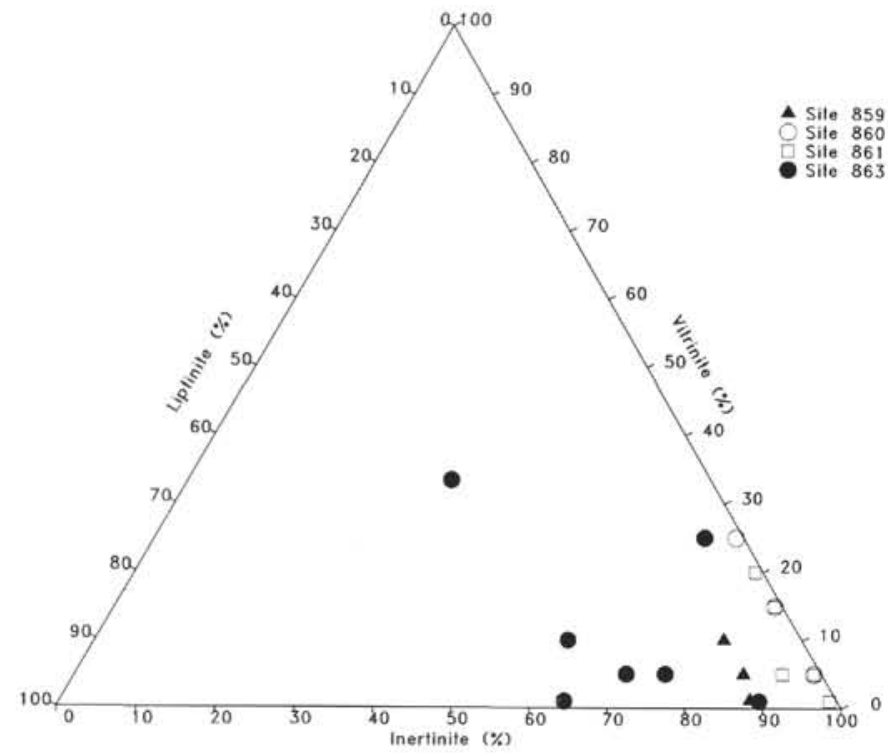

Figure 6. Ternary diagram with percentages of liptinite, vitrinite, and inertinite in samples from the Chile continental margin (see Table 3). The same diagram with comparison data for typical coal-bearing strata and deep-sea sediments from the Brazil and Philippine basins and the Galicia and Northwest African continental margins was published by Littke (1993).

abundant than liptinite and less abundant than inertinite at Site 859. This decrease of vitrinite percentages with increasing distance from the coastline (Table 1) is the result of the chemical instability of vitrinite precursors in oxic environments. A purely hydrodynamic effect (settling of vitrinite particles close to the coastline) is not sufficient to explain the above observations, because it would lead to a decrease in both inertinite and vitrinite content.

At Sites 860 and 861 , maceral composition is more dominated by inertinite. Liptinite percentages are extremely low at these locations and much lower than at Site 859. On the other hand, vitrinite percentages are higher at Sites 860 and 861 . The higher vitrinite contribution is explained by the proximity to the coast as the source for both vitrinite and inertinite. Comparing Rock-Eval and microscopy data, the high OI values fit well to the observed maceral composition whereas the low liptinite percentages seem to contrast with the relatively high $\mathrm{HI}$ values of samples from Site 861 (Tables 2 and 3). No convincing explanation for this discrepancy can be offered here.

At Site 863, the maceral composition in the deeper part of the drilled section is characterized by higher liptinite percentages than at the other sites (Table 3 ). The high liptinite content is reflected in low OI values, but unexpectedly not in $\mathrm{HI}$ values greater than $200 \mathrm{mg} \mathrm{hc} / \mathrm{g}$ TOC (Table 2) despite the analysis of kerogen concentrates which should not show any mineral matrix effects artificially lowering HI values in organic-matter-lean sediments. Orange (rather than yellow) fluorescing alginite was observed only in Sample 141-863B-41R-3, 92-97 cm. This color change may indicate an enhanced maturation of the organic matter at the respective depth (about $670 \mathrm{mbsf}$ ), which was also indicated by the corresponding $\mathrm{T}_{\max }$ value. Based on liptinite fluorescence, all other samples have to be regarded as immature with respect to the onset of petroleum generation.

In summary, the microscopic results indicate that the organic matter is predominately composed of inertinite. Marine-derived alginite is most abundant at Site 863 and very rare at the near-continent Sites 861 and 860 .

\section{NONAROMATIC HYDROCARBONS}

Yields of bitumen extractable from relatively young and shallow deep-sea sediments are usually low $(<20 \mathrm{mg} / \mathrm{g}$ TOC if dichlorometh-
Table 2. Hydrogen index, oxygen index, and $T_{\max }$ values as determined by Rock-Eval pyrolysis for kerogen concentrates (first value) and whole rocks (second value) from off the coast of Chile.

\begin{tabular}{|c|c|c|c|c|}
\hline $\begin{array}{l}\text { Core, section. } \\
\text { interval }(\mathrm{cm})\end{array}$ & $\begin{array}{l}\text { Depth } \\
\text { (mbsf) }\end{array}$ & $\begin{array}{c}\text { HI } \\
\text { (mg hc/g TOC) }\end{array}$ & $\begin{array}{c}\mathrm{OI} \\
\text { (mg CO} / \mathrm{g} \text { TOC) }\end{array}$ & $\begin{array}{l}\mathrm{T}_{\max } \\
\left({ }^{\circ} \mathrm{C}\right)\end{array}$ \\
\hline $\begin{array}{l}141-859 \mathrm{~A}- \\
2 \mathrm{H}-3.60-66\end{array}$ & 4.80 & $209 / 41$ & $41 / 184$ & $399 / 545$ \\
\hline $\begin{array}{l}141-859 \mathrm{~B}- \\
32 \mathrm{R}-1.77-83 \\
35 \mathrm{R}-2,120-126\end{array}$ & $\begin{array}{l}409.37 \\
440.30\end{array}$ & $\begin{array}{c}82 / 109 \\
108 / 158\end{array}$ & $\begin{array}{c}16 \sqrt{42} \\
39 / 100\end{array}$ & $\begin{array}{l}399 / 535 \\
417 / 401\end{array}$ \\
\hline $\begin{array}{l}|41-86| \mathrm{C}- \\
\text { IH-2, } 76-82 \\
8 \mathrm{H}-2,67-73 \\
21 \mathrm{X}-1,30-36 \\
40 \mathrm{X}-3,30-36\end{array}$ & $\begin{array}{r}2.26 \\
62.17 \\
170.50 \\
337.20\end{array}$ & $\begin{array}{c}349 / 91 \\
199 / 116 \\
213 / 180 \\
294 / 83\end{array}$ & $\begin{array}{l}84 / 244 \\
60 / 147 \\
60 / 145 \\
67 / 232\end{array}$ & $\begin{array}{l}389 / 411 \\
399 / 544 \\
390 / 383 \\
395 / 406\end{array}$ \\
\hline $\begin{array}{l}\text { 141-86ID- } \\
\text { I5R-2.49-55 }\end{array}$ & 477.79 & $172 / 60$ & $39 / 276$ & $407 / 419$ \\
\hline $\begin{array}{r}141-863 \mathrm{~A}- \\
3 \mathrm{H}-3,5-14 \\
26 \mathrm{X}-2,0-6\end{array}$ & $\begin{array}{r}21.15 \\
240.24\end{array}$ & $\begin{array}{l}433 / 72 \\
188 / 33\end{array}$ & $\begin{array}{l}69 / 224 \\
40 / 239\end{array}$ & $\begin{array}{l}404 / 406 \\
405 / 416\end{array}$ \\
\hline $\begin{array}{l}141-863 \mathrm{~B}- \\
25 \mathrm{R}-3,116-122 \\
41 \mathrm{R}-3,92-97 \\
49 \mathrm{R}-3,30-36\end{array}$ & $\begin{array}{l}515.86 \\
669.42 \\
736.50\end{array}$ & $\begin{array}{l}197 / 29 \\
164 / 43 \\
202 / 43\end{array}$ & $\begin{array}{l}25 / 132 \\
29 / 136 \\
15 / 129\end{array}$ & $\begin{array}{l}405 / 416 \\
430 / 420 \\
411 / 424\end{array}$ \\
\hline
\end{tabular}

Table 3. Percentages of maceral groups vitrinite, inertinite, and liptinite, expressed as percentage of total macerals, according to estimates in reflected white and fluorescent light on whole-rock samples embedded perpendicular to bedding.

\begin{tabular}{|c|c|c|c|c|}
\hline $\begin{array}{l}\text { Core, section. } \\
\text { interval }(\mathrm{cm})\end{array}$ & $\begin{array}{l}\text { Depth } \\
\text { (mbsf) }\end{array}$ & $\begin{array}{c}\text { Vitrinite } \\
(\%)\end{array}$ & $\begin{array}{c}\text { Inertinite } \\
(\%)\end{array}$ & $\begin{array}{l}\text { Liptinite } \\
(\%)\end{array}$ \\
\hline \multicolumn{5}{|l|}{$141-859 \mathrm{~B}-$} \\
\hline IIR-I. $104-109$ & 207.44 & 10 & 80 & 10 \\
\hline $23 \mathrm{R}-\mathrm{I}, 40-42$ & 322.30 & $(<5)$ & 80 & 20 \\
\hline $32 \mathrm{R}-1,77-83$ & 409.37 & 5 & 85 & 10 \\
\hline $35 \mathrm{R}-2,120-126$ & 440.30 & 10 & 60 & 30 \\
\hline \multicolumn{5}{|l|}{$141-860 \mathrm{~B}-$} \\
\hline $31 X-3,25-31$ & 255.15 & 15 & 85 & $(<5)$ \\
\hline $51 \times-3.74-80$ & 438.54 & 25 & 75 & $(<5)$ \\
\hline $61 X-5,129-135$ & 528.99 & 5 & 95 & $(<5)$ \\
\hline $64 X-3,37-43$ & 552.57 & 5 & 95 & $(<5)$ \\
\hline \multicolumn{5}{|l|}{ 141-861C- } \\
\hline $\mathrm{IH}-2.76-82$ & 2.26 & 5 & 95 & $(<5)$ \\
\hline $3 \mathrm{H}-3,36-42$ & 15.86 & 5 & 90 & 5 \\
\hline $17 X-1.89-95$ & 139.59 & 0 & 80 & 20 \\
\hline $29 X-1,115-121$ & 238.85 & 20 & 80 & $(<5)$ \\
\hline $36 X-2.79-85$ & 297.89 & 15 & 85 & $(<5)$ \\
\hline $41 X-2,98-104$ & 345.88 & 20 & 80 & $(<5)$ \\
\hline \multicolumn{5}{|l|}{$141-861 \mathrm{D}$} \\
\hline $9 R-2,44-50$ & 421.29 & $(<5)$ & 100 & $(<5)$ \\
\hline \multicolumn{5}{|l|}{$141-863 \mathrm{~A}-$} \\
\hline $1 \mathrm{H}-3,11,3-119$ & 4.13 & 10 & 60 & 30 \\
\hline $2 \mathrm{H}-2.125-131$ & 11.35 & 25 & 70 & 5 \\
\hline \multicolumn{5}{|l|}{$141-863 B-$} \\
\hline $11 \mathrm{R}-1.6-9$ & 376.66 & $(<5)$ & 65 & 35 \\
\hline $25 \mathrm{R}-3,116-122$ & 515.86 & 33 & 33 & 33 \\
\hline $3 \mid R-5,63-69$ & 575.23 & 5 & 75 & 20 \\
\hline $32 R-3,1-7$ & 581.81 & $(<5)$ & 90 & 10 \\
\hline $41 R-3,92-97$ & 669.42 & 5 & 70 & 25 \\
\hline
\end{tabular}

ane or a solvent of similar polarity is used for extraction; Rullkötter et al., 1981; Rullkötter and Welte, 1983). This is a consequence of the low maturity of the organic matter in such sediments. Extractable bitumen yields in the sediments from the Chile Triple Junction in most cases exceed $20 \mathrm{mg} / \mathrm{g}$ TOC (Table 4 ). As there is no systematic change with depth, however, these relatively high values are not necessarily attributable to the high geothermal heat flow in this region but may also be related to normalization artifacts caused by the low organic carbon contents, as observed previously in several cases. The proportions of nonaromatic hydrocarbons in the bitumens vary between 
Table 4. Extract yields, compound class distributions (percentages from liquid chromatographic separation; the residue not eluted from the column covers the difference to $100 \%$ ), vitrinite reflectance values, and molecular compound ratios from gas chromatography and gas chromatography/mass spectrometry analysis of selected sediments from Leg 141.

\begin{tabular}{|c|c|c|c|c|c|c|c|c|c|c|}
\hline $\begin{array}{l}\text { Core, section. } \\
\text { interval }(\mathrm{cm})\end{array}$ & $\begin{array}{l}\text { Depth } \\
\text { (mbsf) }\end{array}$ & $\begin{array}{l}\text { Total extract } \\
\text { (mg/g TOC) }\end{array}$ & $\begin{array}{c}\text { Nonaromatic } \\
\text { hydrocarbons } \\
\text { (\%) }\end{array}$ & $\begin{array}{c}\text { Aromatic } \\
\text { hydrocarbons } \\
\text { (\%) }\end{array}$ & $\begin{array}{l}\text { Hetero- } \\
\text { components } \\
\text { (\%) }\end{array}$ & $\begin{array}{l}\mathrm{R}_{\mathrm{r}} \\
(\%)\end{array}$ & $\begin{array}{c}\text { CPI } \\
(25-31)\end{array}$ & $\mathrm{Pr} / \mathrm{ph}$ & $\mathrm{Ph} / n-\mathrm{C}_{1 \mathrm{x}}$ & $22 \mathrm{~S} /(22 \mathrm{~S}+\mathrm{R})$ \\
\hline $\begin{array}{l}141-859 \mathrm{~A}- \\
2 \mathrm{H}-3,60-66\end{array}$ & 4.80 & 61 & 10 & 2 & 17 & ND & 4.8 & 1.1 & 0.9 & 0.14 \\
\hline $\begin{array}{l}141-859 \mathrm{~B}- \\
29 \mathrm{R}-3,45-51 \\
32 \mathrm{R}-1,77-83 \\
35 \mathrm{R}-2,120-126\end{array}$ & $\begin{array}{l}382.95 \\
409.37 \\
440.30\end{array}$ & $\begin{array}{l}43 \\
22 \\
33\end{array}$ & $\begin{array}{r}15 \\
11 \\
3\end{array}$ & $\begin{array}{r}4 \\
4 \\
36\end{array}$ & $\begin{array}{l}74 \\
59 \\
55\end{array}$ & $\begin{array}{l}\text { ND } \\
0.45 \\
0.51\end{array}$ & $\begin{array}{l}4.3 \\
2.2 \\
\text { ND }\end{array}$ & $\begin{array}{l}0.8 \\
0.5 \\
\text { ND }\end{array}$ & $\begin{array}{r}1.6 \\
3.0 \\
\mathrm{ND}\end{array}$ & $\begin{array}{l}0.08 \\
0.33 \\
0.34\end{array}$ \\
\hline $\begin{array}{l}141-86 \mid \mathrm{C}- \\
1 \mathrm{H}-2,76-82 \\
8 \mathrm{H}-2,67-73 \\
21 \mathrm{X}-1,30-36 \\
40 \mathrm{X}-3,30-36\end{array}$ & $\begin{array}{r}2.26 \\
62.17 \\
170.50 \\
337.20\end{array}$ & $\begin{array}{l}17 \\
19 \\
46 \\
27\end{array}$ & $\begin{array}{r}10 \\
12 \\
3 \\
7\end{array}$ & $\begin{array}{r}5 \\
5 \\
65 \\
2\end{array}$ & $\begin{array}{l}59 \\
79 \\
21 \\
78\end{array}$ & $\begin{array}{l}\text { ND } \\
\text { ND } \\
\text { ND } \\
\text { ND }\end{array}$ & $\begin{array}{l}3.3 \\
6.4 \\
5.8 \\
3.7\end{array}$ & $\begin{array}{l}1.2 \\
1.4 \\
1.3 \\
1.1\end{array}$ & $\begin{array}{l}0.9 \\
0.9 \\
0.9 \\
0.9\end{array}$ & $\begin{array}{l}\text { ND } \\
0.19 \\
\text { ND } \\
0.03\end{array}$ \\
\hline $\begin{array}{l}\text { 141-861D- } \\
\quad \text { 15R-2, 49-55 }\end{array}$ & 477.79 & 50 & 8 & 2 & 48 & ND & 4.4 & 1.2 & 0.7 & ND \\
\hline $\begin{array}{r}141-863 \mathrm{~A}- \\
3 \mathrm{H}-3,5-14 \\
26 \mathrm{X}-2,0-6\end{array}$ & $\begin{array}{r}21.15 \\
240.24\end{array}$ & $\begin{array}{r}2.38 \\
29\end{array}$ & $\begin{array}{r}3 \\
18\end{array}$ & $\begin{array}{r}<1 \\
9\end{array}$ & $\begin{array}{r}4 \\
68\end{array}$ & $\begin{array}{l}0.34 \\
0.36\end{array}$ & $\begin{array}{l}5.3 \\
3.6\end{array}$ & $\begin{array}{l}1.6 \\
1.2\end{array}$ & $\begin{array}{l}0.8 \\
0.9\end{array}$ & $\begin{array}{l}\text { ND } \\
\text { ND }\end{array}$ \\
\hline $\begin{array}{l}141-863 \mathrm{~B}- \\
25 \mathrm{R}-3.116-122 \\
41 \mathrm{R}-3,92-97 \\
49 \mathrm{R}-3,30-36\end{array}$ & $\begin{array}{l}515.86 \\
669.42 \\
736.50\end{array}$ & $\begin{array}{l}29 \\
40 \\
29\end{array}$ & $\begin{array}{l}11 \\
14 \\
16\end{array}$ & $\begin{array}{r}7 \\
14 \\
17\end{array}$ & $\begin{array}{l}62 \\
66 \\
64\end{array}$ & $\begin{array}{l}0.34 \\
0.36 \\
0.41\end{array}$ & $\begin{array}{l}1.5 \\
3.1 \\
2.8\end{array}$ & $\begin{array}{l}1.1 \\
0.9 \\
1.4\end{array}$ & $\begin{array}{l}3.3 \\
3.1 \\
3.8\end{array}$ & $\begin{array}{l}\text { ND } \\
0.06 \\
0.14\end{array}$ \\
\hline
\end{tabular}

Note: $22 \mathrm{~S} /(22 \mathrm{~S}+22 \mathrm{R})$ ratio of 30 -homo-17 $\alpha$-hopanes from $\mathrm{m} / 2191$ mass chromatograms.

about $3 \%$ and $18 \%$ of the total extracts, whereas the proportions of aromatic hydrocarbons - with the exception of the anomalous values attributed to analytical errors for two sediment samples from Cores 141-859B-35R and 141-861C-21X - are considerably lower in most of the samples studied (Table 4). For both hydrocarbon fractions these proportions are in the range expected for sediments containing immature organic matter (e.g., Rullkötter et al., 1988).

Nonaromatic hydrocarbon distributions typical of sediments recovered from offshore Chile during ODP Leg 141 are shown in Figure $7 \mathrm{~A}-\mathrm{F}$ for samples mostly from the deeper parts of Holes 859B, 861C, and 863B. All analyzed samples from Site 861 are characterized by high concentrations of odd-carbon-numbered $n$-alkanes with 25 to 33 carbon atoms derived from epicuticular waxes of higher land plants (e.g., Eglinton and Hamilton, 1963; Figs. 7A and B). A second $n$-alkane maximum at about $\mathrm{n}-\mathrm{C}_{16}$ is much less pronounced. Concentrations of the isoprenoid hydrocarbons pristane and phytane as well as those of polycyclic nonaromatic hydrocarbons including triterpenoids and steroids are also low. This pattern, in addition to being influenced by the low thermal maturity of the organic matter, indicates the predominance of terrigenous over marine organic matter and confirms the microscopic results, because the molecular composition of organic matter in deep sea sediments with abundant marine organic matter preservation is reflected in elevated relative concentrations of isoprenoid and steroid hydrocarbons (e.g., Rullkötter et al., 1981, 1984; Stein, Rullkötter, and Welte, 1989). There is no indication of an impregnation of the sediments at Site 861 by migrated bitumen from parts of the basin where the organic matter might be more mature.

At the more distal Site 859 , a bimodal distribution of $n$-alkanes was found (Fig. 7C). The high concentrations of odd-numbered $n$-alkanes with 25 to 33 carbon atoms (i.e., CPI values in Table 4) indicate a significant contribution of terrigenous material to the total organic matter, whereas the high concentration of $n$-alkanes with 16 to 20 carbon atoms may indicate an additional contribution by marine algae or an admixture of migrated hydrocarbons from deeper, more mature sources; the well-pronounced unresolved complex mixture underlying the shorter-chain $n$-alkanes appears to support the latter interpretation (see also Kvenvolden et al., this volume, for more information).

At Site 863, samples from shallow depths (about 21 and $240 \mathrm{mbsf}$; Fig. 7D) show an $n$-alkane pattern that is roughly similar to that found at Site 861 (Figs. 7A and B). Samples from greater depth $(515,669$, and $736 \mathrm{mbsf}$ ) exhibit a strikingly different pattern (Figs. 7E and F, respectively, for the latter two depths). Polycyclic nonaromatic hydrocarbons are approximately as abundant as long-chain $n$-alkanes from higher plants as already evident from initial GC analyses performed aboard JOIDES Resolution (Behrmann, Lewis, Musgrave, et al., 1992). Also, the isoprenoid hydrocarbons pristane and phytane have relative concentrations significantly exceeding those in all other samples investigated. These data indicate a much better preservation of marine organic matter in these samples, but may at the same time be attributable to a more advanced level of diagenesis that led to the formation of a more complex mixture of hydrocarbons from functionalized precursors in the bitumen or the kerogen as observed in deep sea sediments from other areas of high heat flow (e.g., Rullkötter et al., 1981). The increase in the phytane $/ n-\mathrm{C}_{18}$ ratio with depth at Site 863 (Table 4) corroborates the latter interpretation.

Distributions of steroid hydrocarbons for five selected samples are shown in Figures $8 \mathrm{~A}-\mathrm{E}$ with the corresponding individual compounds identified in Table 5. The two sediments from Site 861, which are poor in biological markers as mentioned before (gas chromatograms in Fig. 7 ), contain mainly unsaturated sterenes and only traces of saturated steranes. In the shallower sediment $(62.17 \mathrm{mbsf}$; Fig. $8 \mathrm{~A})$ the most abundant single compounds are $\mathrm{C}_{27}$ to $\mathrm{C}_{29}$ ster-2-enes, the most unstable sterene species among the isomers commonly occurring in geological samples (van Graas et al., 1982). Progress in diagenesis in the deeper sample ( $337.20 \mathrm{mbsf}$; Fig. $8 \mathrm{~B}$ ) is obvious from the appearance and the relative abundance of ster-4- and -5-enes. A series of additional significantly abundant compounds in the shallower sample with a mass spectrometric key fragment at $\mathrm{m} / \mathrm{z} 298$ probably are side-chain unsaturated sterenes structurally not identified in detail.

A different steroid hydrocarbon pattern was found for Sample 141-859-32R-1, 77-83 cm (409.37 mbsf). Sterenes are still present, but in very low relative concentrations (Fig. $8 \mathrm{C} ; \mathrm{m} / \mathrm{z} 215$ trace). Saturated steranes are dominant $(\mathrm{m} / \mathrm{z} 217$ trace). They include isomers of regular steranes with steric configurations typical of mature organic matter (20S-epimers; Table 4) as well as diasteranes also more common in sediments with mature organic matter and in crude oils. Unsaturated diasterenes are minor constituents. It is not clear whether the unknown compounds marked in the $\mathrm{m} / \mathrm{z} 231$ trace are steroid 

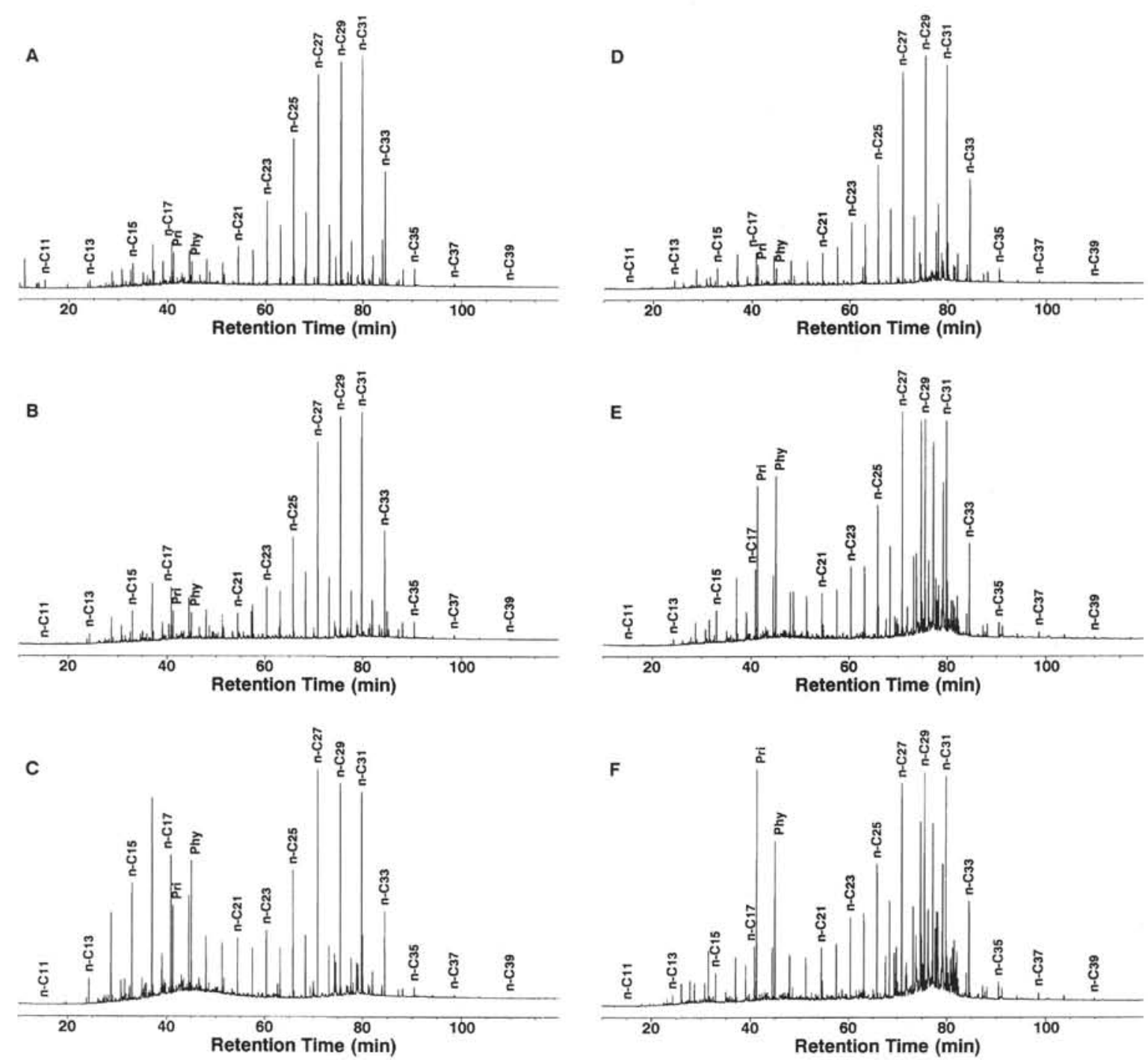

Figure 7. Capillary gas chromatograms of the saturated-hydrocarbon fractions of selected samples from Sites 861,859 , and 863 . A. Sample 141-861C-8H-2, 67-73 cm (62.17 mbsf). B. Sample 141-861C-40X-3, 30-36 cm (337.20 mbsf). C. Sample 141-859B-29R-3, 45-51 cm (382.95 mbsf). D. Sample 141-863A-26X-2, 0-6 cm (240.24 mbsf). E. Sample 141-863B-4IR-3, 92-97 cm (669.42 mbsf). F. Sample 141-863CB-49R-3, 30-36 cm (736.50 mbsf). Vertical axis is flame ionization detector response scaled to the most intense peak, horizontal axis is retention time. Numbers indicate carbon numbers of straight-chain alkanes, pr is pristane, ph is phytane.

hydrocarbons or not. The carbon number distributions of the steroids identified in this sample and those from Site 861 indicate that they originate from marine biomass (Huang and Meinschein, 1976).

The sediments from the deep part of Hole 863B were shown before to be rich in biological marker hydrocarbons (Fig. 7). The distribution patterns in the two selected samples shown in Figures 8D and $\mathrm{E}$ differ significantly from those described before. Saturated steranes dominate but are present as $5 \beta$ - and $5 \alpha$-isomers with $20 R$ configuration only. They are accompanied by a series of diasterenes that are more abundant in the deepest sample studied. In addition, 4-methylsteranes with 30 carbon atoms form an isomer cluster typical of dinosteranes (Summons et al., 1987). The presence of these compounds, the occurrence of abundant 24-propylcholestane and 24-nordiasterenes, in addition to the sterane carbon number distribution are strong evidence for a predominant contribution of marine organic matter to these sediments (Moldowan et al., 1990, 1991; Peters and Moldowan, 1993), as far as it is represented in the bitumen fraction.

Other significant biological marker hydrocarbons in the sediments studied are of microbial origin. They comprise hopenes and hopanes as the most prominent compound classes (Ourisson et al., 1979) and varying amounts of fernenes (Brassell et al., 1981). Both sediment samples from Site 861 have almost identical triterpenoid hydrocarbon distributions (Figs. 9A and 9B; compound identification: Table 6). Saturated hopanes dominate in the $\mathrm{m} / \mathrm{z} 191$ trace. The amounts of unsaturated hopenes are surprisingly small for the shallow burial depth and, thus, difficult to explain. Among the saturated hopanes, those with the biogenic $17 \beta$-configuration dominate but moretanes and particularly 30 -homo-17 $\alpha$-hopane are unusually abundant for sediments from such shallow depths. Among the three isomeric fernenes the most stable isomer with the double bond in the $9(11)$ position dominates but the least stable fernene isomer, fern-7-ene (Ageta et al., 1987), is still present.

Sample 141-859B-32R-1, 77-83, (Fig. 9C) contains an unusual mixture of $17 \alpha$-hopanes typical of more mature organic matter and $17 \beta$-hopanes and moretanes more common at the level of advanced diagenesis together with hopenes usually occurring in immature sediments. Fernenes are restricted to the two more stable isomers, and fern-7-ene was not detected. The $17 \alpha$-hopanes extend only up to $C_{31}$ in the sediments from Site 863 (Figs. 9D and E) compared with $\mathrm{C}_{35}$ in the sample from Hole 859B (Fig. 9C). Unsaturated hopenes are 


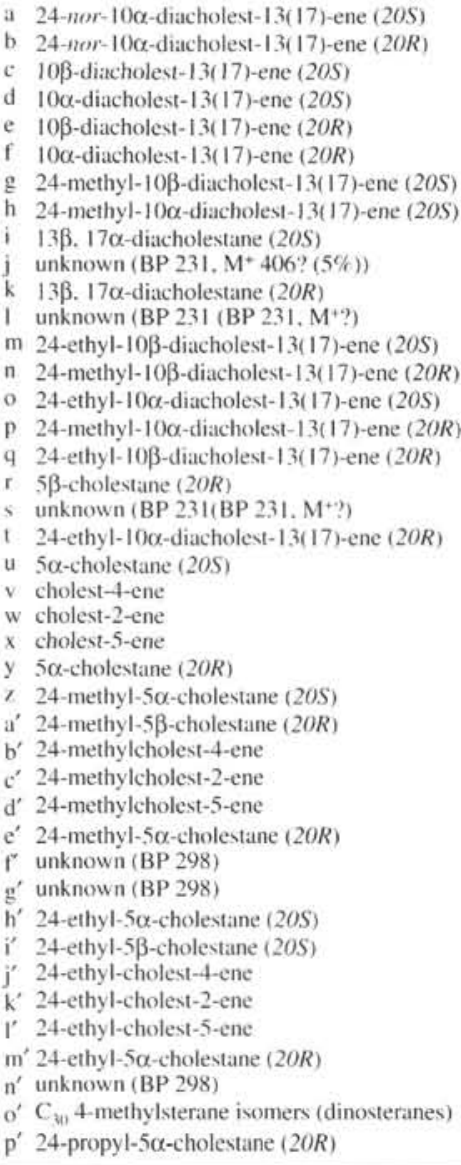

significant constituents, as are hopanes with the biogenic $17 \beta$-configuration. Both samples from Site 863 have triterpenoid hydrocarbon distributions similar to each other. The lower hopane/sterane ratio indicates less bacterial reworking than in the other samples studied. The absence of fernenes is consistent with this.

\section{MATURITY}

Some maturity information was obtained from $\mathrm{T}_{\max }$ values and fluorescence colors, which both indicate that the organic matter is immature. A possible exception may be the deeper part (about 670 mbsf) at Site 863, but this was deduced from data and observations on only one sample. More quantitative information on organic matter maturity is provided by (1) vitrinite reflectance data $\left(R_{r}\right),(2)$ carbon preference index (CPI) values, and (3) biomarker maturity parameters. The respective values are listed in Table 4.

Vitrinite reflectance values were measured only on kerogen concentrates prepared from samples from the deeper sections at Sites 859 and 863 . For the shallower sediments at these locations and for sediments at Sites 860 and 861 , it was assumed that organic matter generally is immature (Behrmann, Lewis, Musgrave, et al., 1992). Mean vitrinite reflectance values obtained for the two samples from Site 859 differ considerably $(0.30 \%$ and $0.45 \%$; see Table 4$)$. The higher value for the deeper sample is regarded as an indication of the absence of autochthonous vitrinite; in this case the higher value results from the measurement of reflectance on reworked vitrinite
A 22.29,30-trinor-hop-17(21)-ene

B 22.29,30-trinor-17 $\alpha$-hopane

C 22.29.30-trimor-17 $\beta$-hopane

D $\mathrm{C}_{2 x}$-triterpane $\left(\mathrm{M}^{+} 384\right)$

E $\mathrm{C}_{2 \times}$-triterpene $\left(\mathrm{M}^{+} 382\right)$

$\mathrm{F}$ C $\mathrm{C}^{-}$- triterpune $\left(\mathrm{M}^{+} 384\right)$

G ${ }_{3 \times}$-triterpane $\left(\mathrm{M}^{+} 384\right)$

G 30-nor-hop-17(21)-ene

H 30-nor-neohop-13(18)-ene

I 30-nor-17 $\alpha$-hopane

J 30-nor-neohopane

$\mathrm{K}$ hop-17(21)-ene

L. 30-nor-moretanc

M 17 $\alpha$-hopane

$\mathrm{N}$ fern-8-ene

O neohop-13(18)-ene

P 30-nor-17\-hopane

$Q$ fern-9(11)-ene

$R$ moretane

$S$ fern-7-ene

T 30-homo-17 $\alpha$-hopane (2OS)

U 30-homo-17 $\alpha$-hopane (20R)

V 17/-hopane

W 30-homo-moretane

$X$ 30-dihomo-17 $\alpha$-hopane (20S)

Y 30-dihomo-17 $\alpha$-hopane (20R)

Z 30-homo-17ß-hopane

A' 30-dihomo-17ß-hopane

B' 30-trihomo-17 $\alpha$-hopane (20S)

$\mathrm{C}^{\prime}$ 30-trihomo-17 $\alpha$-hopane (20R)

D' 30-tetrakishome-17 $\alpha$-hopane (20S)

$E^{\prime}$ 30-tetrakishomo-17 $\alpha$-hopane (2OR)

$F^{\prime}$ 30-pentakishomo-17 $\alpha$-hopane 20S)

Y 30-pentakishomo-17 $\alpha$-hopane $(20 R)$

particles. The lower value is regarded as a more accurate indicator of the thermal history of sediments at Site 859.

At Site 863, vitrinite reflectance values increase little with depth. For three samples between 240 and 670 mbsf, mean reflectance values between $0.34 \%$ and $0.36 \%$ were established. A slightly higher value of $0.41 \%$ resulted for the deepest sample at $736 \mathrm{mbsf}$ (see Table 4). All reflectance data suggest that the sediments did not reach the threshold value for thermal petroleum generation given in textbooks (usually about $0.5 \% \mathrm{R}_{r}$; see Tissot and Welte, 1984). The invariability of the reflectance values can be tentatively explained by maturation of the now steeply dipping sedimentary sequence prior to tectonic deformation. The slightly higher reflectance value of the lowermost sample may indicate that only the deepest rocks at Site 863 (below 670 mbsf) experienced an additional post-tectonic maturation. It should, however, be noted that reflectance values in immature sediments are greatly facies dependant. Therefore, other explanations for the invariable mean vitrinite reflectance values cannot be ruled out; the absence of autochthonous vitrinite and presence of reworked vitrinite (of about $0.35 \% \mathrm{R}_{\mathrm{r}}$ ) would also explain the described phenomenon. The reflectance data do, however, rule out that maturity significantly exceeds $0.4 \% \mathrm{R}_{\mathrm{r}}$ in any of the drilled sediments at Site 863 .

The reflectance value of $0.41 \%$ at $736 \mathrm{mbsf}$ can be used to calculate, how long elevated temperatures may have influenced the sediments. Assuming a maximum temperature of $100^{\circ} \mathrm{C}$ for these sediments, a duration of this maximum temperature of about $20,000 \mathrm{yr}$ has to be assumed according to Sweeney and Burnham (1990). If peak temperatures had reached $120^{\circ} \mathrm{C}$ in the past, a duration of about $1000 \mathrm{yr}$ would be sufficient to explain the $0.4 \% \mathrm{R}_{\mathrm{r}}$ value.

CPI values for the pentacosane to hentriacontane $\left(n-\mathrm{C}_{25}-n-\mathrm{C}_{31}\right)$ range are high in all analyzed samples, which indicates that the organic matter is immature or only marginally mature (Table 4 ). These $n$-alkanes, thus, are directly inherited from terrigenous higher plants and not diluted with significant amounts of thermally generated hydrocarbons, which because of random carbon-carbon bond cracking would tend to decrease CPI values toward unity. The differences between the 

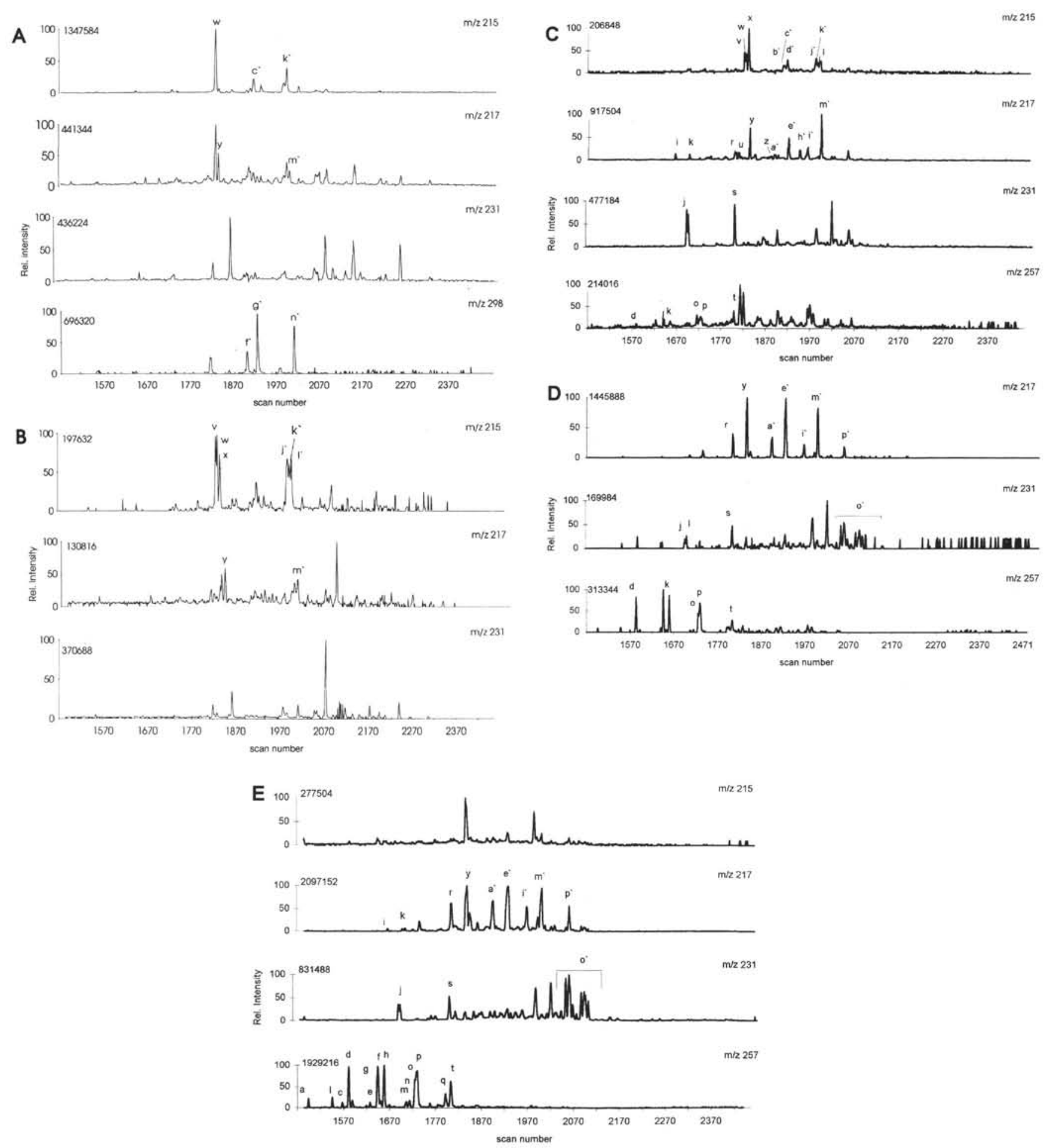

Figure 8. Partial mass fragmentograms of key ions for steroid hydrocarbons ( $\mathrm{m} / \mathrm{z} 215$ : sterenes, $\mathrm{m} / \mathrm{z} 217$ : steranes, $\mathrm{m} / \mathrm{z}$ 231: 4-methylsteranes, $\mathrm{m} / \mathrm{z} 257:$ diasterenes; $\mathrm{m} / \mathrm{z} 298$ : unknown sterenes, probably with double bond in the side chain) from GC-MS analysis of nonaromatic-hydrocarbon fractions in bitumen extracted from selected sediments recovered during Leg 141. A. Sample 141-861C-8H-2, 67-73 cm (62.17 mbsf). B. Sample 141-861C-40X-3, 30-36 cm (337.20 mbsf). C. Sample 141-859B-32R-1, 77-83 cm (409.37 mbsf). D. Sample 141-863B-4IR-3, $92-97$ cm (669.42 mbsf). E. Sample 141-863B-49R-3, 30-36 cm (736.50 mbsf). Vertical axis is relative abundance in percent for each ion trace, horizontal axis is scan number and, implicitly, retention time. For compound identification see Table 5. For technical reasons of data processing for geographical representation, the $\mathrm{m} / \mathrm{z} 231$ traces are slightly offset from other traces. 

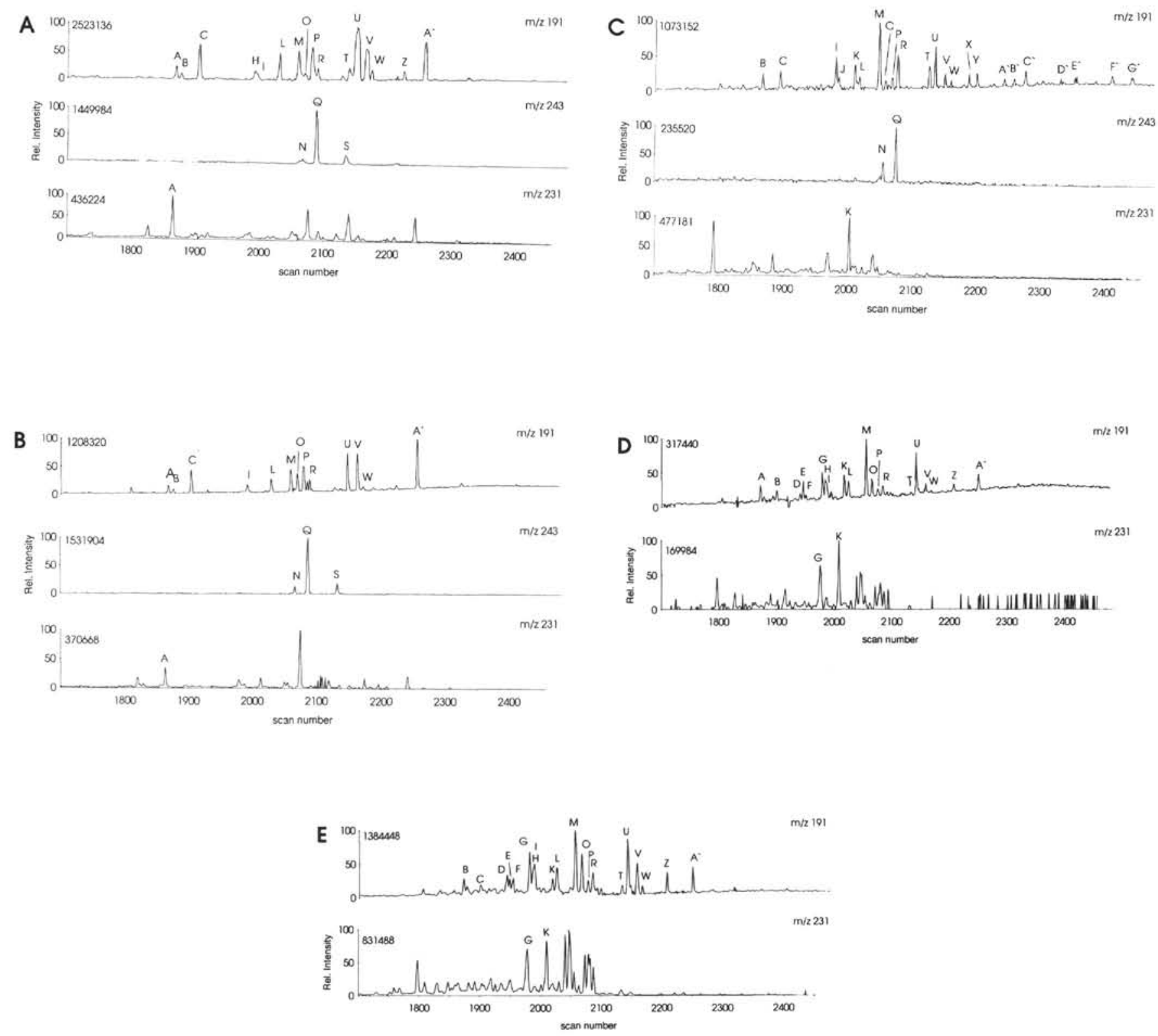

Figure 9. Partial mass fragmentograms of key ions for triterpenoid hydrocarbons $(\mathrm{m} / \mathrm{z} 191$ : most triterpenes and triterpanes, $\mathrm{m} / \mathrm{z} 243$ : fernenes, $\mathrm{m} / \mathrm{z} 231$ : hop-17(21)-enes) from GC-MS analysis of nonaromatic-hydrocarbon fractions in bitumen extracted from selected sediments recovered during Leg 141. A. Sample 141-861C-8H-2, 67-73 cm (62.17 mbsf). B. Sample 141-861C-40X-3, 30-36 cm (337.20 mbsf). C. Sample 141-859B-32R-1, 77-83 cm (409.37 mbsf). D. Sample 141-863B-41 R-3, 92-97 cm (669.42 mbsf). E. Sample 141-863B-49R-3, 30-36 cm (736.50 mbsf). Vertical axis is relative abundance in percent for each ion trace, horizontal axis is scan number and retention time. For compound identification see Table 6.

CPI values of the different samples are probably the result of changes of organic facies rather than to changes of maturity.

Biological marker hydrocarbons exhibit a complex pattern of mixed mature and immature signatures in some of the samples investigated. Samples from Site 861 mostly indicate low maturity (owing to the dominance of sterenes) although the low concentration or absence of hopenes in the presence of abundant saturated analogs is difficult to explain.

Sediments from Site 859 contain varying admixtures of mature hydrocarbons to a background of immature components. This is evident from the dependence of $22 S /(22 S+22 R)$ epimer ratios of extended $17 \alpha$-hopanes on carbon number (Fig. 9C). The $\mathrm{C}_{31}$ pseudo- homologs consistently show lower epimer ratios because they comprise a significant contribution of the indigenous $22 R$ epimer (typical immature signature; Fig. 9B), whereas the $\mathrm{C}_{32}-\mathrm{C}_{35}$ pseudohomologs are uniformly more mature. This can be explained by impregnation of the sediments at Site 859 with migrated mature bitumen. The extent of impregnation varies, as can be seen from the variation of $22 S /(22 S$ $+22 R$ ) epimer ratios for these samples (Table 4). The lack of a systematic downhole trend is evidence against in-situ maturation by locally high heat flow. A similar maturity variation pattern also applies to the $20 S /(20 S+20 R)$ epimer ratio of 24-ethylsteranes (Fig. 8C; see Kvenvolden et al., this volume, for a more detailed discussion). The presence of fernenes, hop-17(21)-ene, neohop-13(18)-ene, and 
sterenes as typical feature of immature organic matter further corroborates the concept of low in-situ maturation. The migrated hydrocarbons may derive from a more mature sediment section, which may be hydrothermally influenced like at vents at the seafloor (Simoneit, 1993, and references therein).

Based on biological marker composition, sediments from Site 863 show an increase in diagenetic transformation with depth as indicated by the $22 S /(22 S+22 R)$ epimer of the $\mathrm{C}_{31}$ homo-17- $\alpha$ hopanes (Figs. 9D and 9E; Table 4), which is consistent with the vitrinite reflectance data. There is no indication of the presence of migrated hydrocarbons in sediments at this site.

\section{CONCLUSIONS}

Sediments from the Chile Triple Junction area recovered during Leg 141 are lean in organic matter, although they are slightly more enriched in organic carbon than average deep-sea sediments. The influence of terrigenous organic matter supply is clearly visible by bulk (Rock-Eval pyrolysis) and molecular ( $n$-alkane distributions) parameters. The farthest landward Site 861 received most of this terrigenous contribution. Marine organic matter was preserved in significant amounts particularly in the deeper sections at Site 863 , as is obvious especially from extractable hydrocarbon analysis.

The high heat flow at the Chile Triple Junction is indeed reflected in the organic matter compositions of the sediments, but it is hard to unravel in detail the timing and duration of elevated heat flow to individual sediment layers at the different sites. Complex molecular biological marker distributions at Site 859 comprising unusual mixtures of mature and immature signals may be interpreted as migrated hydrocarbons from more mature sections. Indigenous maturation apparently is most advanced at Site 863 . In both cases, the proximity to the ridge axis will be responsible for the observed maturation effects.

\section{ACKNOWLEDGMENTS}

Our study greatly benefitted from the analytical support by the technical staff of ICG-4, especially W. Benders, E. Biermanns, F.-J. Keller, W. Laumer, A. Ropertz, and H. Willsch, from the financial support by the Deutsche Forschungsgemeinschaft (grant No. Ru $458 / 1$ ), and from reviews by Drs. Jan Behrmann, Barry J. Katz, and Bernd R.T. Simoneit. Furthermore, thanks are due to the German ODP organization which enabled one of us (R.L.) to participate in the post-cruise meeting at $\mathrm{La} \mathrm{Paz}$.

\section{REFERENCES}

Ageta, H., Shiojima, K., and Arai, Y., 1987. Acid-induced rearrangement of triterpenoid hydrocarbons belonging to the hopane and migrated hopane series. Chem. Pharm. Bull., 35:2705-2716.

Behrmann, J.H., Lewis, S.D., Musgrave, R.J., et al., 1992. Proc. ODP, Init. Repts., 141: College Station, TX (Ocean Drilling Program).

Brassell, S.C., Wardroper, A.M.K., Thomson, I.D., Maxwell, J.R., and Eglinton, G., 1981. Specific acyclic isoprenoids as biological markers of methanogenic bacteria in marine sediments. Nature, 290:693-696.

Davis, E.E., Mottl, M.J., Fisher, A.T., et al., 1992. Proc. ODP, Init. Repts., 139: College Station, TX (Ocean Drilling Program).

Durand, B., 1980. Kerogen: Insoluble Organic Matter from Sedimentary Rocks: Paris (Editions Technip).

Eglinton, G., and Hamilton, R.J., 1963. The distribution of alkanes. In Swain, T. (Ed.), Chemical Plant Taxonomy: London (Academic Press), 187-208.

Espitalié, J., Laporte, J.L., Leplat, P., Madec, M., Marquis, F., Paulet, J., and Boutefeu, A., 1977. Méthode rapide de caractérisation des roches mères,

\footnotetext{
Abbreviations for names of organizations and publications in ODP reference lists follow the style given in Chemical Abstracts Service Source Index (published by American Chemical Society)
}

de leur potentiel pétrolier et de leur degré d'évolution. Rev. Inst. Fr. Pet., 32:23-42.

Huang, W.Y., and Meinschein, W.G., 1976. Sterols as source indicators of organic materials in sediments. Geochim. Cosmochim. Acta, 40:323-330.

Katz, B.J., 1983. Limitations of "Rock-Eval" pyrolysis for typing organic matter. Org. Geochem., 4:195-199.

Leg 141 Shipboard Scientific Party, 1992. Ocean drilling yields surprises at the Chile Triple Junction. Geotimes, 37:19-21.

Lichtfouse, E., Littke, R., Disko, U., Willsch, H., Rullkötter, J., and Stein, R., 1992. Geochemistry and petrology of organic matter in Miocene to Quaternary deep sea sediments from the Japan Sea (Sites 798 and 799). In Pisciotto, K.A., Ingle, J.C., Jr., von Breymann, M.T., Barron, J., et al., Proc. ODP, Sci. Results, $127 / 128$ (Pt. 1): College Station, TX (Ocean Drilling Program), 667-675.

Littke, R., 1993. Deposition, Diagenesis, and Weathering of Organic MatterRich Sediments: Heidelberg (Springer-Verlag).

Littke, R., Rullkötter, J., and Schaefer, R.G., 1991. Organic and carbonate carbon accumulation on Broken Ridge and Ninetyeast Ridge, central Indian Ocean. In Weissel, J., Peirce, J., Taylor, E., Alt, J., et al., Proc. ODP, Sci. Results, 121: College Station, TX (Ocean Drilling Program), 467-489.

Moldowan, J.M., Fago, F.J., Lee, C.Y., Jacobson S.R., Watt, D.S., Slougui, N.-E., Jeganathan, A., and Young, D.C., 1990. Sedimentary 24-n-propylcholestanes, molecular fossils diagnostic of marine algae. Science, 247:309-312.

Moldowan, J.M., Lee, C.Y., Watt, D.S., Jeganathan, A., Slougui, N.E., and Gallegos, E.J., 1991. Analysis and occurrence of C26-steranes in petroleum and source rocks. Geochim. Cosmochim. Acta, 55:1065-1081.

Ourisson, G., Albrecht, P., and Rohmer, M., 1979. The hopanoids: paleochemistry and biochemistry of a group of natural products. Pure Appl. Chem., 51:709-729.

Parson, L., Hawkins, J., Allan, J., et al., 1992. Proc. ODP, Init. Repts., 135: College Station, TX (Ocean Drilling Program).

Peters, K.E., and Moldowan, J.M., 1993. The Biomarker Guide: Englewood Cliffs, NJ (Prentice Hall)

Radke, M., Sittardt, H.G., and Welte, D.H., 1978. Removal of soluble organic matter from rock samples with a flow-through extraction cell. Anal. Chem., 50:663-665.

Radke, M., Willsch, H., and Welte, D.H., 1980. Preparative hydrocarbon group type determination by automated medium pressure liquid chromatography. Anal. Chem., 52:406-411.

Rullkötter, J., Leythaeuser, D., Horsfield, B., Littke, R., Mann, U., Müller, P.J., Radke, M., Schaefer, R.G., Schenk, H.-J., Schwochau, K., Witte, E.G., and Welte, D.H., 1988. Organic matter maturation under the influence of a deep intrusive heat source: a natural experiment for quantitation of hydrocarbon generation and expulsion from a petroleum source rock (Toarcian shale, northern Germany). In Mattavelli, L., and Novelli, L. (Eds.), Advances in Organic Geochemistry 1987: Oxford (Pergamon Press), 847-856.

Rullkötter, J., Mukhopadhyay, P.K., Schaefer, R.G., and Welte, D.H., 1984. Geochemistry and petrography of organic matter in sediments from Deep Sea Drilling Project Sites 545 and 547, Mazagan Escarpment. In Hinz, K., Winterer, E.L., et al., Init. Repts. DSDP, 79: Washington (U.S. Govt. Printing Office), 775-806.

Rullkötter, J., von der Dick, H., and Welte, D.H., 1981. Organic petrography and extractable hydrocarbons of sediments from the eastern North Pacific Ocean, Deep Sea Drilling Project Leg 63. In Yeats, R.S., Haq, B.U., et al., Init. Repts. DSDP, 63: Washington (U.S. Govt. Printing Office), 819-836.

Rullkötter, J., and Welte, D.H., 1983. Maturation of organic matter in areas of high heat flow: a study of sediments from DSDP Leg 63, offshore California, and Leg 64, Gulf of California. In Bjorøy, M., Albrecht, P., Cornford, C., de Groot, K., Eglinton, G., Galimov, E., Leythaeuser, D., Pelet, R., Rullkötter, J., and Speers, G., (Eds.), Advances in Organic Geochemistry 1981: Chichester (Wiley), 438-448.

Schenk, H.J., Witte, E.G., Littke, R., and Schwochau, K., 1990. Structural modifications of vitrinite and alginite concentrates during pyrolytic maturation at different heating rates. Org. Geochem., 16:943-950.

Simoneit, B.R.T., 1982. Organic geochemistry, Leg 64: introduction and summary. In Curray, J.R., Moore, D.G., et al., Init. Repts. DSDP, 64 (Pt. 2) Washington (U.S. Govt. Printing Office), 717-721

, 1993. Hydrothermal alteration of organic matter in marine and terrestrial systems. In Engel, M.H., and Macko, S.A. (Eds.), Organic Geochemistry: New York (Plenum), 397-418.

Stein, R., Littke, R., Stax, R., and Welte, D.H., 1989. Quantity, provenance, and maturity of organic matter at ODP Sites 645, 646, and 647: implications for reconstruction of paleoenvironments in Baffin Bay and Labrador 
Sea during Tertiary and Quaternary time. In Srivastava, S.P., Arthur, M.A., Clement, B., et al., Proc. ODP, Sci. Results, 105: College Station, TX (Ocean Drilling Program), 185-208.

Stein, R., Rullkötter, J., and Welte, D.H., 1989. Changes in palaeoenvironments in the Atlantic Ocean during Cretaceous times: results from black shales studies. Geol. Rundsch., 78:883-901.

Stein, R., ten Haven, H.L., Littke, R., Rullkötter, J., and Welte, D.H., 1989. Accumulation of marine and terrigenous organic carbon at upwelling Site 658 and nonupwelling Sites 657 and 659: implications for the reconstruction of paleoenvironments in the eastern subtropical Atlantic through late Cenozoic times. In Ruddiman, W., Sarnthein, M., et al., Proc. ODP, Sci. Results, 108: College Station, TX (Ocean Drilling Program), 361-385.

Summons, R.E., Volkman, J.K., and Boreham, C.J., 1987. Dinosterane and other steroidal hydrocarbons of dinoflagellate origin in sediments and petroleum. Geochim. Cosmochim. Acta, 51:3075-3082.

Sweeney, J.J., and Burnham, A.K., 1990. Evaluation of a simple model of vitrinite reflectance based on chemical kinetics. AAPG Bull., 74:15591570.

ten Haven, H.L., Littke, R., Rullkötter, J., Stein, R., and Welte, D.H., 1990. Accumulation rates and composition of organic matter in late Cenozoic sediments underlying the active upwelling area off Peru. In Suess, E., von
Huene, R., et al., Proc. ODP, Sci. Results, 112: College Station, TX (Ocean Drilling Program), 591-606.

Tissot, B.P., and Welte, D.H., 1984. Petroleum Formation and Occurrence (2nd ed.): Heidelberg (Springer-Verlag).

van Andel, T.H., Heath, G.R., and Moore, T.C., Jr., 1975. Cenozoic history and paleoceanography of the central equatorial Pacific Ocean. Mem.-Geol. Soc. Am., 143.

van Graas, G., Baas, J.M.A., van de Graaf, B., and de Leeuw, J.W., 1982. Theoretical organic geochemistry: I. The thermodynamic stability of several cholestane isomers calculated by molecular mechanics. Geochim. Cosmochim. Acta, 46:2399-2402.

von der Dick, H., Rullkötter, J., and Welte, D.H., 1983. Content, type and thermal evolution of organic matter in sediments from the eastern Falkland Plateau, Deep Sea Drilling Project, Leg 71. In Ludwig, W.J., Krasheninnikov, V.A., et al., Init. Repts. DSDP, 71 (Pt. 2): Washington (U.S. Govt. Printing Office), 1015-1032.

Date of initial receipt: 13 September 1993

Date of acceptance: 19 January 1994

Ms 141SR-004 